\title{
Massive asphalt deposits, oil seepage, and gas venting support abundant chemosynthetic communities at the Campeche Knolls, southern Gulf of Mexico
}

\author{
Heiko Sahling ${ }^{1,2}$, Christian Borowski ${ }^{2,3}$, Elva Escobar-Briones ${ }^{4}$, Adriana Gaytán-Caballero ${ }^{4}$, Chieh-Wei Hsu ${ }^{1}$, \\ Markus Loher ${ }^{2}$, Ian MacDonald ${ }^{5}$, Yann Marcon ${ }^{6}$, Thomas Pape ${ }^{1,2}$, Miriam Römer ${ }^{1,2}$, Maxim Rubin-Blum ${ }^{3}$, \\ Florence Schubotz ${ }^{2}$, Daniel Smrzka ${ }^{7}$, Gunter Wegener ${ }^{2,3}$, and Gerhard Bohrmann ${ }^{1,2}$ \\ ${ }^{1}$ Department of Geosciences at the University of Bremen, Klagenfurter Str., 28359 Bremen, Germany \\ ${ }^{2}$ MARUM Center for Marine Environmental Sciences, Leobener Str., 28359 Bremen, Germany \\ ${ }^{3}$ Max-Planck Institute for Marine Microbiology, Celsiusstr. 1, 28359 Bremen, Germany \\ ${ }^{4}$ Universidad Nacional Autónoma de México, Instituto de Ciencias del Mar y Limnología, \\ A. P. 70-305 Ciudad Universitaria, 04510 Mexico City, México \\ ${ }^{5}$ Florida State University, P.O. Box 3064326, Tallahassee, FL 32306, USA \\ ${ }^{6}$ Alfred Wegener Institute Helmholz Centre for Polar and Marine Research, HGF-MPG Group for Deep Sea Ecology \\ and Technology, Am Handelshafen 12, 27570 Bremerhaven, Germany \\ ${ }^{7}$ Center for Earth Sciences, University of Vienna, Althanstr. 14, 1090 Vienna, Austria
}

Correspondence to: Heiko Sahling (hsahling@marum.de)

Received: 17 March 2016 - Published in Biogeosciences Discuss.: 24 March 2016

Revised: 29 June 2016 - Accepted: 19 July 2016 - Published: 11 August 2016

\begin{abstract}
Hydrocarbon seepage is a widespread process at the continental margins of the Gulf of Mexico. We used a multidisciplinary approach, including multibeam mapping and visual seafloor observations with different underwater vehicles to study the extent and character of complex hydrocarbon seepage in the Bay of Campeche, southern Gulf of Mexico. Our observations showed that seafloor asphalt deposits previously only known from the Chapopote Knoll also occur at numerous other knolls and ridges in water depths from 1230 to $3150 \mathrm{~m}$. In particular the deeper sites (Chapopopte and Mictlan knolls) were characterized by asphalt deposits accompanied by extrusion of liquid oil in form of whips or sheets, and in some places (Tsanyao Yang, Mictlan, and Chapopote knolls) by gas emission and the presence of gas hydrates in addition. Molecular and stable carbon isotopic compositions of gaseous hydrocarbons suggest their primarily thermogenic origin. Relatively fresh asphalt structures were settled by chemosynthetic communities including bacterial mats and vestimentiferan tube worms, whereas older flows appeared largely inert and devoid of corals and anemones at the deep sites. The gas hydrates at Tsanyao Yang and Mictlan Knolls were covered by a 5-to- $10 \mathrm{~cm}$-thick
\end{abstract}

reaction zone composed of authigenic carbonates, detritus, and microbial mats, and were densely colonized by $1-2 \mathrm{~m}$ long tube worms, bivalves, snails, and shrimps. This study increased knowledge on the occurrences and dimensions of asphalt fields and associated gas hydrates at the Campeche Knolls. The extent of all discovered seepage structure areas indicates that emission of complex hydrocarbons is a widespread, thus important feature of the southern Gulf of Mexico.

\section{Introduction}

Asphalt volcanism in the Campeche Knolls, southern Gulf of Mexico (GoM) has been described as a distinct form of natural hydrocarbon seepage (MacDonald et al., 2004). Heavy oil is extruded and forms lava-like flows that cover $\sim 100$ to $\sim 1000 \mathrm{~m}^{2}$ of abyssal knolls and ridges (Brüning et al., 2010). The flows consist of high-density oil with an abundant asphaltene fraction (MacDonald et al., 2004) with a terpane composition similar to what has been reported from some crude oils in the Bay of Campeche (Scholz-Böttcher 
et al., 2008; Schubotz et al., 2011b). As described by Brüning et al. (2010), the heavy oil is at a transition point between mobile and immobile when it flows; fluid-phase material can spread smoothly over the seafloor and, because its density is initially less than seawater, local bulges and "whips" occur due to buoyancy. After exposure to seawater, the heavy oil solidifies to brittle layers because of weathering processes and loss of volatile hydrocarbons. Fissures and cracks through the solidified asphalt deposits were observed to develop with time. Fragmentation of brittle asphalt proceeds until cobble-to-boulder-sized pieces become buried by sedimentation (Brüning et al., 2010).

Most of the research conducted so far concentrated on the type locality, Chapopote Knoll, which was named after the Aztec word for tar. Because it forms a knoll with a central crater-like depression with extensive hard substrata, the term "asphalt volcano" was introduced for Chapopote Knoll (MacDonald et al., 2004). Chapopote Knoll is suggested to overlie a reservoir-seal system for hydrocarbons. From seismic studies it was inferred that coarse-grained sediments sealed by a thin (100-200 m) veneer of fine-grained sediments within the core of the knoll act as a temporal hydrocarbon reservoir (Ding et al., 2008). Ding et al. (2008) speculated that the shallow reservoir plays a role in creating a heavy oil prior to its seafloor discharge: the oil in the region forms from Jurassic source material that has solidified within the hydrocarbon generation window over an extended time period (Magoon et al., 2001). Processes such as biodegradation, water washing, or gas injection in the shallow reservoir could further increase its specific gravity (Tissot and Welte, 1984). However, Schubotz et al. (2011b) did not find evidence for biodegradation in ductile (fresh) asphalts, so the sequence leading to the characteristic asphalt deposition remains speculative. In the Campeche Knolls, oil seepage is widespread as evidenced by sea surface oil slicks detected by synthetic aperture radar satellite images (Fig. 1; Williams et al., 2006). The sea surface slicks occur above dozens of knolls and ridges (Ding et al., 2010) and are thus a significant component of natural seepage in the south-western Gulf of Mexico (MacDonald et al., 2015). Seismic studies at the knolls and ridges indicate shallow subsurface hydrocarbon accumulation as well (Ding et al., 2010) but prior to the present study it was unclear whether these systems also produced asphalt deposits at the seafloor.

The natural hydrocarbon seeps at Chapopote Knoll comprise typical seep components that provide habitat for diverse biological communities. For example, in addition to asphalt deposits, there are reports of oil-soaked sediments (MacDonald et al., 2004; Schubotz et al., 2011a, b), gas hydrate occurrences (MacDonald et al., 2004, Schubotz et al., 2011b, Klapp et al., 2010a, b), gas venting (Brüning et al., 2010), and authigenic carbonates (Naehr et al., 2009). The asphalt deposits sustain hydrocarbon-degrading and sulfatereducing bacteria within their interiors (Schubotz et al., 2011b), as well as surface bacterial mats and vestimen-

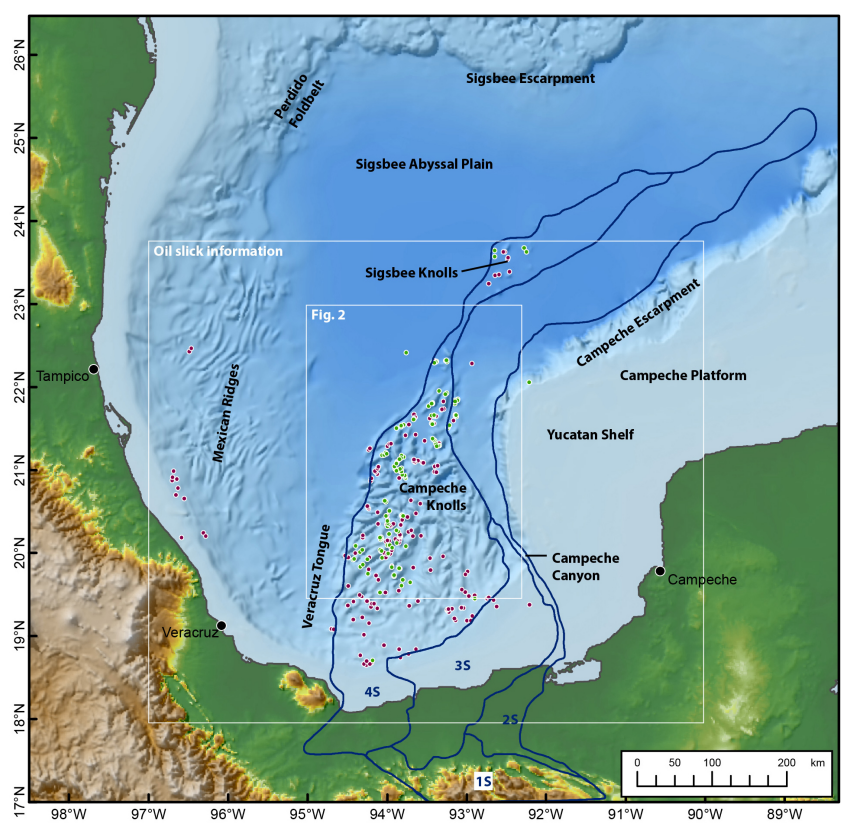

Figure 1. Geomorphological setting of the southern Gulf of Mexico based on shaded GEBCO (General Bathymetric Chart of the Oceans) bathymetry. The Campeche Knolls and Sigsbee Knolls are located within the subprovince 4 S, which is part of the South Gulf Salt Province (outlined in blue) as suggested by Cruz-Mercado et al. (2011). Locations of definite (green dots) and probable (purple dots) oil slick origins at the sea surface according to Williams et al. (2006) and the extent of the respective study area (outer rectangle) are shown.

tiferan tube worms that colonize fissures in the asphalt deposits (MacDonald et al., 2004; Brüning et al., 2010). Oilimpregnated sediments were found to harbour a complex microbial community which sustained both methanotrophy and methanogenesis (Schubotz et al., 2010a, b). The stable isotopes of methane in gas hydrates associated with asphalt suggested methanogenesis (Schubotz et al., 2011b). Two species of mytilid mussel (Bathymodiolus brooksi and B. haeckerae) occurred close to an oil and gas seep, harbouring different endosymbiotic communities (Raggi et al., 2013). A novel symbiont related to the hydrocarbon-degrading bacteria genus Cycloclasticus was verified in the seep-associated mussel $B$. haeckerae (Raggi et al., 2013).

Subsequent to the initial discovery at Chapopote Knoll (MacDonald et al., 2004) asphalt deposits were found at other continental margin settings as well. In the Santa Barbara Basin off California, asphalt volcanoes about 15 and $20 \mathrm{~m}$ high formed 31 to $44 \mathrm{kyr}$ ago (Valentine et al., 2010). These structures occur at water depths of around 150 to $180 \mathrm{~m}$ in a region additionally comprising tar mounds at $\sim 30 \mathrm{~m}$ depths (Vernon and Slater, 1963). In the northern Gulf of Mexico, asphalt mounds about $1 \mathrm{~m}$ in height and up to several metres in basal diameter exist in the Puma appraisal area (Weiland et al., 2008) and the Shenzi field 
(Williamson et al., 2008) at water depths of about $1500 \mathrm{~m}$. In addition, more than 2000 asphalt mounds with diameters ranging from less than a metre up to $50 \mathrm{~m}$ were observed on the Angolan margin at a water depth between 1350 and $2150 \mathrm{~m}$ (Jones et al., 2014). Based on their morphological appearance, their partial coverage by sediments, and the general lack of chemosynthetic organisms growing on the asphalt, the asphalt deposits in other regions seem to be older than those described in the southern GoM (Brüning et al., 2010). Moreover, in contrast to those in the southern GoM, asphalt deposits in the other regions are populated by regular, heterotrophic deep-sea organisms growing on hard substrate. Old asphalt deposits have therefore been suggested to foster the deep-sea habitat heterogeneity and provide additional settling grounds for species dispersal, which results in an increase in overall diversity (Jones et al., 2014). The Campeche Knoll asphalt region remains the deepest example known to date. The potential influence of pressure and temperature on emission of asphalt, liquid oil, and gas and their interaction with microbial and metazoan communities warrants further investigation.

We conducted an interdisciplinary research campaign at the Campeche Knolls in spring 2015 on board the R/V Meteor. Sites for investigation were developed following a nested approach. We used the information of oil slicks at the sea surface (Williams et al., 2006; MacDonald et al., 2015; Suresh, 2015) to systematically identify potential targets with active hydrocarbon systems. To further focus our activities, we looked for evidence of gas bubble emissions by scanning the water column with a ship-based hull-mounted multibeam echosounder. High-resolution bathymetry of the most promising sites was acquired by the SEAL 5000 autonomous underwater vehicle (AUV) mapping. Finally, we conducted seafloor observations and sampling by QUEST $4000 \mathrm{~m}$ remotely operated vehicle (ROV), concentrating on three sites at depths $>2900 \mathrm{~m}$. Specifically, we were interested in disentangling the various seafloor manifestations resulting from the geochemically diverse seepage of heavy oil (leading to asphalt deposits), oil (leading to sea surface slicks), and gas (as bubbles and hydrate deposits). By concentrating on the description of the different environments that we encountered at the hydrocarbon seeps, we provide an overview for more detailed studies that will focus on the geochemistry of different oils, authigenic carbonate composition, microbiology, and fauna. We additionally show, based on our recent findings and results obtained during three precursor cruises (Bohrmann and Schenk, 2004; Bohrmann et al., 2008; MacDonald et al., 2007), that asphalt deposits are not limited to the type locality Chapopote Knoll, but are inherent to natural hydrocarbon seepage in the entire Campeche Knolls.

\section{Geological setting of the Campeche Knolls}

The Campeche Knolls (Fig. 1) are part of the large South Gulf Salt Province that stretches from the southern land margin across the shelf and the Campeche Knolls to the Sigsbee Knolls in the north. The Sigsbee Abyssal Plain separates the salt province in the southern GoM from the MississippiTexas-Louisiana salt province in the north. Salt tectonism in the southern deep GoM basin is believed to be an analogue to that of the Texas-Louisiana slope (Garrison and Martin, 1973). Because the basins share similar salt deposition histories, it is inferred that most of the salt was deposited during the rifting stage of the gulf in the Late Jurassic, equivalent to the Louann salt of the Texas-Louisiana slope (Salvador, 1991).

The Campeche Knolls comprise knolls and ridges that are limited to the west by smooth abyssal seafloor of the salt-free Veracruz tongue (Bryant et al., 1991). The Campeche Canyon, which is not a canyon in erosional sense, formed through the development of the eastern limit of the Campeche Knolls and the carbonate Campeche Platform. Northward, smooth seafloor separates the Campeche Knolls from the Sigsbee Knolls. The Campeche Knolls are covered by a $5-10 \mathrm{~km}$ sediment column that hosts prolific petroleum source rocks, with the most productive being of Late Jurassic and Cretaceous age (Magoon et al., 2001). Most of the sediment thickness results from deposition during Cenozoic times and was controlled by orogenic events in the Mexican region and sea-level changes.

The distribution of oil slicks at the sea surface (Williams et al., 2006; MacDonald et al., 2015; Suresh, 2015) aggregates along the north-western sector of the Campeche Knolls (Fig. 1). Interpretation of seismic lines and basin modelling carried out by the Mexican petroleum company PEMEX led to the conclusion that the subprovince designated as $4 \mathrm{~S}$ (Fig. 1) contains the largest allochthonous and autochthonous salt deposits (Cruz-Mercado et al., 2011; Sánchez-Rivera et al., 2011). The actual density of salt bodies increases from the south-east to the north-western region of the Campeche Knolls. It is proposed that gravitational forces toward the north-west cause contraction and compression in the northwestern distal part of the system in which structural folds, high-angle reverse faults, and numerous allochthonous salt bodies developed since the late Miocene (Cruz-Mercado et al., 2011; Sánchez-Rivera et al., 2011).

\section{Material and methods}

Natural oil slicks at the sea surface were detected by synthetic aperture radar in the region of the southern GoM by Williams et al. (2006). Based on their analyses of repeated observations, they postulated seep locations on the seafloor that could be the origins of the oil slicks. With regard to interpretation limits of the remotely sensed data they distin- 
guished between definite, probable, and possible seep locations. Figures 1 and 2 show the inferred seep locations they classified as definite or probable. We excluded the numerous possible seep locations for clarity and because many of the possible seeps were located outside of Campeche Knolls, suggesting that the corresponding oil slicks might not be caused by natural oil seepage. Those sea surface patterns might have been caused by other processes, i.e. algae blooms, local wind fields, or anthropogenic activity.

Ship-based hydroacoustic surveys and dives with an autonomous underwater vehicle (AUV) and a remotely operated vehicle (ROV) were conducted during cruise $\mathrm{R} / \mathrm{V} \mathrm{Me}$ teor (M 114) from 12 February to 28 March 2015.

The multibeam echosounder (MBES) Kongsberg EM122 operating at $12 \mathrm{kHz}$ was used for bathymetric mapping. Together with bathymetry data collected during two earlier cruises with R/V Sonne in 2003 (SO 174; Bohrmann and Schenk, 2004) and R/V Meteor (M67/2; Bohrmann et al., 2008), good bathymetric coverage was acquired in the entire north-western sector of the Campeche Knolls (Fig. 2).

We additionally examined the water column data of the MBES systematically for evidence of gas emissions along the entire cruise track of M 114 (Fig. 2, inset). Water column imaging for the detection of gas bubble plumes was conducted with the Fledermaus Midwater software programme (company: Quality Positioning Services B. V., the Netherlands). Gas bubble plumes cause high backscatter in the water column. In this paper we assume that all acoustic anomalies were related to gas venting and will refer to them as "flares". Flares were traced through the water column by analysing swath by swath, which results in a threedimensional representation of the bubble streams. We detected numerous gas bubble flares, some of which could be traced completely from the water column down to the seabed. Most flares, however, were only observed in the midwater column and the point of origin at the seabed could not be traced. In those instances, we projected the flares down to the seafloor and give this point as a coordinate. We assume that this lack of backscatter from gas bubbles in great water depths results from the pressure dependence of the backscatter strength (Greinert et al., 2006). Further in-depth studies are required to confirm this. For the objectives of this study, we linearly projected flares from midwater depths to the seabed and assumed that bubbles were escaping the seafloor around these sites. We defined survey areas at the seafloor, which included the putative gas emission sites, and conducted AUV-based micro-bathymetric mapping and ROVmounted horizontally scanning sonar to locate gas emission sites.

High-resolution bathymetry data were acquired with the MBES Kongsberg 2040 during dives with the AUV SEAL 5000 at an altitude of $80 \mathrm{~m}$. Ship-based and AUV-based bathymetry data were processed with MB-Systems (Caress and Cheyes, 2014).

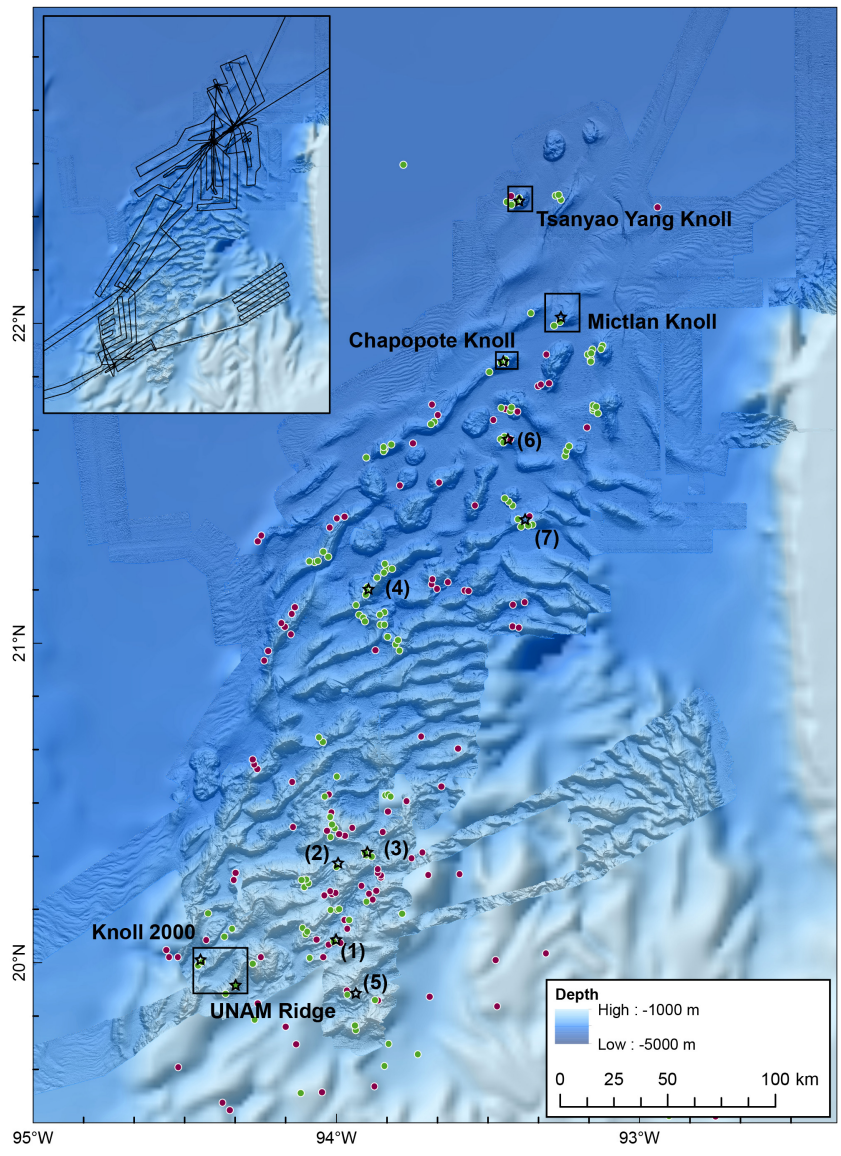

Figure 2. Swath bathymetry draped over GEBCO bathymetry of the Campeche Knolls and cruise track of M 114 (inset). Indicated are oil slick origins as inferred from oil slicks at the sea surface according to Williams et al. (2006), classified as definite (green dots) and probable (purple dots). Seafloor locations of hydrocarbon seepage sites investigated in this study are also shown (open stars, number in brackets). Specifics of those sites are given in Table 1.

The Kongsberg $675 \mathrm{kHz}$ Type 1071 forward-looking sonar on ROV QUEST $4000 \mathrm{~m}$ was used for the localization of bubble plumes following the method described in Nikolovska et al. (2008). Seafloor images shown in this study were taken either with the digital Inside Pacific Scorpio 3.3 megapixel still camera or frame-grabbed (Adobe Premiere Pro) from video footage gained with the Insite Pacific Zeus 3CCD HDTV video camera.

In order to geochemically characterize the different hydrocarbon components, gas bubbles (clear and oil coated) and oil drops released from the seafloor were captured with the pressure-tight gas bubble sampler (GBS) at four different knolls and ridges (Supplement Table 1). Two bubble streams were sampled at Tsanyao Yang Knoll whereas at all other investigated sites only one bubble stream was sampled. Gas bubble samples were not recovered from Knoll 2000. Repeated sampling was conducted at Mictlan Knoll during different dives and at different heights above the seafloor. Oil 
drops were captured together with chimney-like structures at Marker M114-5 at a site similar in appearance to that shown in Fig. 6d. The samples were analysed for molecular compositions and $\delta^{13} \mathrm{C}-\mathrm{CH}_{4}$ signatures according to Pape et al. (2010) and Römer et al. (2012). Biological samples were taken by push corer, scoop net, manipulator, or baited trap with the help of the ROV. Based on the video footage and studies of the animals on board, we identified the fauna to various taxonomic levels but detailed onshore studies are needed to fully explore their taxonomy.

Underwater navigation of AUV and ROV were achieved by use of the IXSEA Posidonia ultrashort baseline system. Spatial data were integrated into the Arc-GIS programme (ESRI) and maps were produced by combined usage of the Arc-GIS and Adobe Illustrator programmes.

Camera sled surveys were conducted during cruises SO 174 (Bohrmann and Schenk, 2004), M 67/2 (Bohrmann et al., 2008), and Chapopote III with R/V Justo Sierra in 2007 (MacDonald et al., 2007). Three different camera systems were used for taking video images (M 67/2 and Chapopote III) and photographs (SO 174) at the seafloor. The locations of camera sled observations given in Table 1 are approximated based on ship position.

\section{Results}

\subsection{Site descriptions}

\subsubsection{Tsanyao Yang Knoll (about $3400 \mathrm{~m}$ water depth)}

Tsanyao Yang Knoll is a dome approximately $400 \mathrm{~m}$ high and $6 \mathrm{~km}$ wide (Fig. 3a), which we named after Prof. Tsanyao Yang from the Department of Geosciences, National University of Taiwan. "Frank" Yang dedicated his life to studying mud volcanoes and hydrocarbon seeps on- and offshore Taiwan; he sadly passed away while we were conducting this present study at sea.

Gas emissions were recorded as flares with the echosounder from the seafloor at water depths as great as $3500 \mathrm{~m}$ at the plateau-like summit (Fig. 3a). Figure 3b shows the ROV dive track within a depression about 150 to $200 \mathrm{~m}$ wide and $30 \mathrm{~m}$ deep. Here, we discovered spectacular gashydrate exposures at three sites (Site 1, 2, and 3) at depths of about $3420 \mathrm{~m}$. In contrast to the knolls and ridges further south, we did not observe widespread asphalt deposits during the dives at Tsanyao Yang Knoll.

The gas hydrates were found in mounds that were 1-2 m high and 3-10 $\mathrm{m}$ wide at their bases and densely colonized by vestimentiferan tube worms, probably of the genus Escarpia (Fig. 4a). The mounds had regular borders of gravelto-boulder-sized rock clasts and shells that separated seepinfluenced sediments from normal deep-sea sediments. In some locations, clusters of living vesicomyid clams (Abyssogena southwardae) were observed in the transition zone. In several instances, the mounds were fractured, exposing 1$2 \mathrm{~m}$ hanging walls of gas hydrate with vigorous gas bubble streams observed emitting from the base (Fig. 4b). Exposed hydrate preserved a fabric of frozen bubbles, which indicated rapid formation (Suess et al., 2001). Some bubble-fabric gas hydrate formed from rising bubbles when they attached to the vertical wall due to adhesion or were captured by overhanging structures. Many bubble streams were composed of transparent bubbles forming white gas hydrates but some streams contained oil-coated bubbles forming blackish-coloured hydrates. We additionally observed dense hydrate cropping out over most of the visible exposed fracture, as exemplified in Fig. 4b. Most of the hydrate was white, but blackish-stained hydrate was also observed.

The outermost 5 to $10 \mathrm{~cm}$-thick layer of the mounds were composed of authigenic carbonates entangled with the posterior parts of the vestimentiferan tubes and other detritus. For convenience, we term these tube worm parts the "rhizosphere" hereafter. Fleshy, thick microbial mats were attached to the carbonates in the lower portion of the rhizosphere. We hypothesize that the carbonates were formed under anoxic conditions in the interior of the rhizosphere, similar to those authigenic carbonates growing in the sediments within the sulfate-methane transition zone at other seeps (Formolo et al., 2004). A flourishing ecosystem of seep-typical fauna (e.g. living mytilid mussels, gastropods, Alvinocaris sp. shrimp) occupied the top of the carbonates at the base of the vestimentiferan tubes (Fig. 4c). The vestimentiferan tubes were densely overgrown by colonies of epifaunal suspension feeders (e.g. hydrozoans and anemones).

At site 3, we observed a mound composed of reworked sediment components and gravel-to-pebble-sized rocks (Fig. 4d). An exposed lens-shaped chunk of hydrate ( $1.5 \mathrm{~m}$ wide and $0.5 \mathrm{~m}$ high) was present at the top of the mound (Fig. 4f). The upper part of the hydrate showed a dense fabric while the lower part was porous, suggesting that it formed from frozen gas bubbles (Fig. 4f). The two hydrate fabrics were separated by a layer that looked like organic material. Ice worms (cf. Hesiocaeca methanicola) were observed living in the bubble-fabric hydrate.

\subsubsection{Mictlan Knoll (about $3100 \mathrm{~m}$ water depth)}

Mictlan Knoll features the characteristics of an asphalt volcano (sensu MacDonald et al., 2004) with a crater-like summit area on top of an approximately $250 \mathrm{~m}$-high circular knoll, which is about $10 \mathrm{~km}$ wide at its base (Fig. 5a). This knoll contained diverse and widespread structures related to heavy oil seepage. We named it Mictlan, which means underworld in the Aztec language.

The MBES surveys revealed evidence for gas emission along the crater rim. We conducted five ROV dives on different areas of the crestal region (Fig. 5b) and illustrate our findings with images from four sites: Hydrate Hill, Marker M114-5, Marker M114-1, and "fresh asphalts". 
Table 1. Summary of evidence for hydrocarbon seepage in the southern Gulf of Mexico based on AUV SEAL 5000, ROV QUEST 4000 m, and camera sled observations obtained during cruises R/V Sonne cruise 174, R/V Meteor cruise 67/2, R/V Justo Sierra cruise Campeche III, and R/V Meteor cruise 114/2. The positions marked with an asterisk are based on ship positions.

\begin{tabular}{|c|c|c|c|c|}
\hline $\begin{array}{l}\text { Seafloor Struc- } \\
\text { ture }\end{array}$ & Location & Depth & Tools & Observation \\
\hline $\begin{array}{l}\text { Tsanyao Yang } \\
\text { Knoll }\end{array}$ & $\begin{array}{l}22^{\circ} 23.55^{\prime} \mathrm{N} \\
93^{\circ} 24.33^{\prime} \mathrm{W}\end{array}$ & $3420 \mathrm{~m}$ & $\begin{array}{l}\text { M 114/2 ROV Dive } 358 \text { (15 Mar 2015), } \\
\text { Dive 361 (19 Mar 2015), AUV Dive } 69 \\
\text { (24 Feb 2015) }\end{array}$ & $\begin{array}{l}\text { Vestimentifera on hydrate outcrops, } \\
\text { gas bubble, and oil emission, } \\
\text { carbonates, mytilid and vesicomyid } \\
\text { bivalves }\end{array}$ \\
\hline
\end{tabular}

\begin{tabular}{lll}
\hline Mictlan Knoll & $22^{\circ} 1.4^{\prime} \mathrm{N} ;$ & $3180 \mathrm{~m}$ \\
& $93^{\circ} 14.9^{\prime} \mathrm{W}$ &
\end{tabular}

M 114/2 ROV Dive 355 (11 Mar 2015), Dive 357 (14 Mar 2015), Dive 360 (18 Mar 2015), Dive 363 (21 Mar 2015), Dive 364 (22 Mar 2015), AUV Dive 68 (23 Feb 2015)

\begin{tabular}{lll}
\hline Chapopote & $21^{\circ} 53.95^{\prime} \mathrm{N} ;$ & $2920 \mathrm{~m}$ \\
Knoll & $93^{\circ} 26.25^{\prime} \mathrm{W}$ &
\end{tabular}

SO 174 OFOS 13 (1 Nov 2003), OFOS 14 (2 Nov 2013); M 67/2 ROV Dive 80 (10 Apr 2006), Dive 81 (11 Apr 2006), Dive 82 (12 Apr 2016), Dive 83 (14 Apr 2006), Dive 84 (15 Apr 2006); M 114/2 ROV Dive 354 (10 Mar 2015), Dive 356 (13 Mar 2015), Dive 359 (16 Mar 2015), Dive 363 (21 Mar 2015), AUV Dive 70 (25 Feb 2015)

\begin{tabular}{|c|c|c|c|c|}
\hline UNAM ridge & $\begin{array}{l}19^{\circ} 55.90^{\prime} \mathrm{N} \\
94^{\circ} 20.89^{\prime} \mathrm{W}\end{array}$ & $1230 \mathrm{~m}$ & $\begin{array}{l}\text { M 114/2 ROV Dive } 351 \text { (4 Mar 2015), } \\
\text { Dive 352 (5 Mar 2015) }\end{array}$ & $\begin{array}{l}\text { Asphalt deposits, carbonates, } \\
\text { vestimentifera, mytilidae, gas bubble } \\
\text { emission }\end{array}$ \\
\hline 1 & $\begin{array}{l}20^{\circ} 4.95^{\prime} \mathrm{N} \\
93^{\circ} 57.85^{\prime} \mathrm{W}^{*}\end{array}$ & $1300 \mathrm{~m}$ & $\begin{array}{l}\text { R/V Justo Sierra camera survey, } \\
\text { Site L89 (18 Sep 2007) }\end{array}$ & Asphalt, vestimentifera, soft coral \\
\hline 2 & $\begin{array}{l}20^{\circ} 19.55^{\prime} \mathrm{N} \\
93^{\circ} 59.15^{\prime} \mathrm{W}^{*}\end{array}$ & $1780 \mathrm{~m}$ & $\begin{array}{l}\text { R/V Justo Sierra camera survey, } \\
\text { Site L87 (20 Sep 2007) }\end{array}$ & $\begin{array}{l}\text { Asphalt or carbonate pieces, } \\
\text { sparse bacterial mats }\end{array}$ \\
\hline 3 & $\begin{array}{l}20^{\circ} 22.02^{\prime} \mathrm{N} \\
93^{\circ} 54.28^{\prime} \mathrm{W}^{*}\end{array}$ & $1700 \mathrm{~m}$ & $\begin{array}{l}\text { R/V Justo Sierra camera survey, } \\
\text { Site L86 (21 Sep 2007) }\end{array}$ & Asphalt, tube worm, mussels \\
\hline 6 & $\begin{array}{l}21^{\circ} 39.5^{\prime} \mathrm{N} \\
93^{\circ} 26.1^{\prime} \mathrm{W}^{*}\end{array}$ & $2980 \mathrm{~m}$ & M 67/2 TV-Sled survey (9 Apr 2006) & $\begin{array}{l}\text { Asphalt deposits some } 10 \mathrm{~m} \\
\text { in diameter }\end{array}$ \\
\hline 7 & $\begin{array}{l}\mathrm{Ca} 21^{\circ} 25^{\prime} \mathrm{N} ; \\
93^{\circ} 22^{\prime} \mathrm{W}^{*} \text { and } \\
21^{\circ} 23.8^{\prime} \mathrm{N} ; \\
93^{\circ} 23.3^{\prime} \mathrm{W}^{*}\end{array}$ & $2400-2440 \mathrm{~m}$ & $\begin{array}{l}\text { SO } 174 / 2 \text { OFOS } 10(29 \text { Oct } 2003), \\
\text { OFOS } 12(31 \text { Oct } 2003)\end{array}$ & $\begin{array}{l}\text { Sediment covered, outcropping } \\
\text { asphalts, scattered living vesicomyid } \\
\text { clams, vestimentifera, bacterial mats }\end{array}$ \\
\hline
\end{tabular}

Hydrate Hill is a $30 \mathrm{~m}$-high elevation with a densely populated vestimentiferan tube worm field (cf. Escarpia spp.) on its top which was 20 to $30 \mathrm{~m}$ wide (Fig. 6a-c). At the summit, gas escaped the seafloor and gas hydrates occurred be- low an overhanging protrusion consisting of carbonates and vestimentifera. Exposed rocks at the base of the hill appeared to be fragmented asphalts (Fig. 6c) but no samples were recovered. We therefore suggest that the entire hill is an ac- 

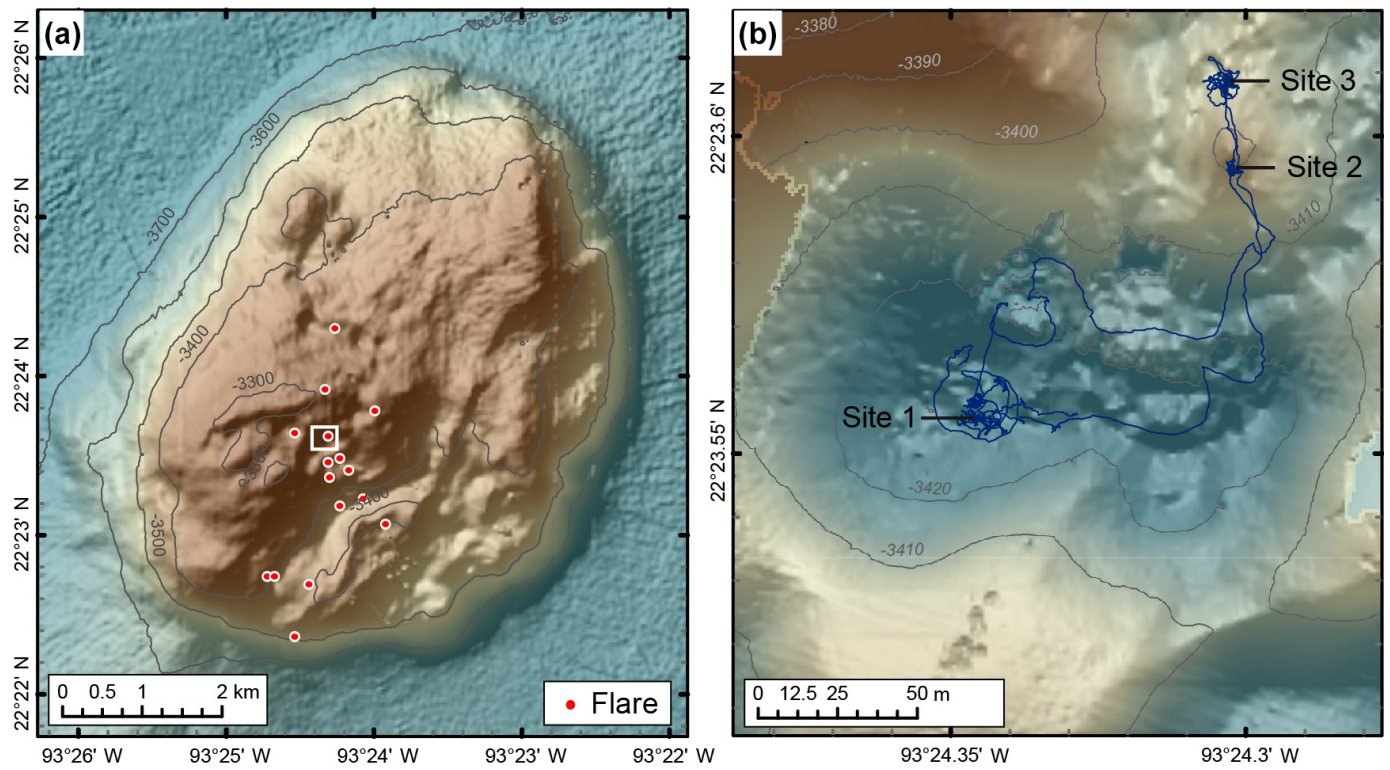

Figure 3. (a) Ship-based swath bathymetry of Tsanyao Yang Knoll (see Fig. 2 for location), flare locations (red dots), and the area shown in (b) (box). (b) ROV QUEST Dive 361 track and the main study sites plotted on AUV swath bathymetry.

cumulation of asphalt talus that is covered at its summit by authigenic carbonates and vestimentifera.

At Marker M114-5, we observed 1-2 m-sized asphalt humps with small colonies of vestimentiferan tube worms that were less than $1 \mathrm{~m}$ long. Remarkably, at this site viscous oil was slowly seeping (about one drop every few minutes) through slender, white-coated chimneys some $10-30 \mathrm{~cm}$ in height (Fig. 6d). In the area around Marker M114-5 about 10 sites with chimney clusters were observed.

At Marker M114-1, oil seepage occurred through a flattopped mound about $1 \mathrm{~m}$-high and tens of metres wide, which was composed of fragmented asphalt and soft sediments. The mound surface was covered by a highly patchy community of $50 \mathrm{~cm}$-long vestimentiferan tube worms, mytilid bivalves (Bathymodolus brooksi), bacterial mats, and various epizoic groups of suspension feeders such as sponges, hydrozoa, and anemones (Fig. 6e, f). Oil drops escaped the sediments at a low rate (one drop of oil every $1-5 \mathrm{~min}$ ). Rising drops at first remained attached to the seafloor by elongating threads and only eventually broke loose, leaving behind strands of oil that floated or adhered to the nearby organisms. Oil was also released from the sediments during sampling of sediments and organisms collected with the ROV and the sample material was heavily soaked with oil when recovered aboard ship.

In the area denoted "fresh asphalts" (Fig. 5b), we observed a variety of structures that provide insight into the flow behaviour of heavy oil deposition at the seafloor. Although the extrusion process of heavy oil was not directly observed by us at the seafloor, the resulting flow structures are illustrative. Based on our observations, two main types of heavy-oil emission and post-emission behaviour may be distinguished.
The first type includes extrusion of heavy oil forming strands or sheets that float into the water due to positive buoyancy while they remain attached to the seabed owing to cohesion (Fig. 7a-c). Over time, the strands and sheets apparently lose buoyancy and pile up on the seafloor forming decimetre-tometre-high accumulations. The second type comprises extrusion of oil that is heavier than seawater and spreads on the seabed following gravity (Fig. 7d-f). These flows solidify over time and, subsequently, accumulate sediments on their surface as illustrated in Fig. 7e and f. Dimensions of flows observed in this study ranged between decimetre and tens of metres in diameter.

\subsubsection{Chapopote Knoll (about $2900 \mathrm{~m}$ water depth)}

Flare mapping with the ship-based MBES system revealed that plumes interpreted to be due to gas emission at this site were widespread along the crater rim (Fig. 8a). Flares were rather dispersed; consequently, we mapped areas with gas emissions rather than individual emission sites. Subsequent ROV dives focused on the $50 \mathrm{~m}$-wide flow of the main asphalt field and a location that had been named the "bubble site" during previous visits (Fig. 8b; Brüning et al., 2010).

The first analysis of the results obtained during our return visit in 2015 revealed that the appearance of the main asphalt field was little altered from what was observed during the first exploration in 2006 (Brüning et al. 2010). The extent of the flow and distributions of bacterial mats and vestimentiferan tube worm remained largely unchanged. While expanding the mapped area in the course of this study, it became apparent that the main asphalt flows terminated on soft sediments in the north and west (Fig. 9a), but overlaid older 

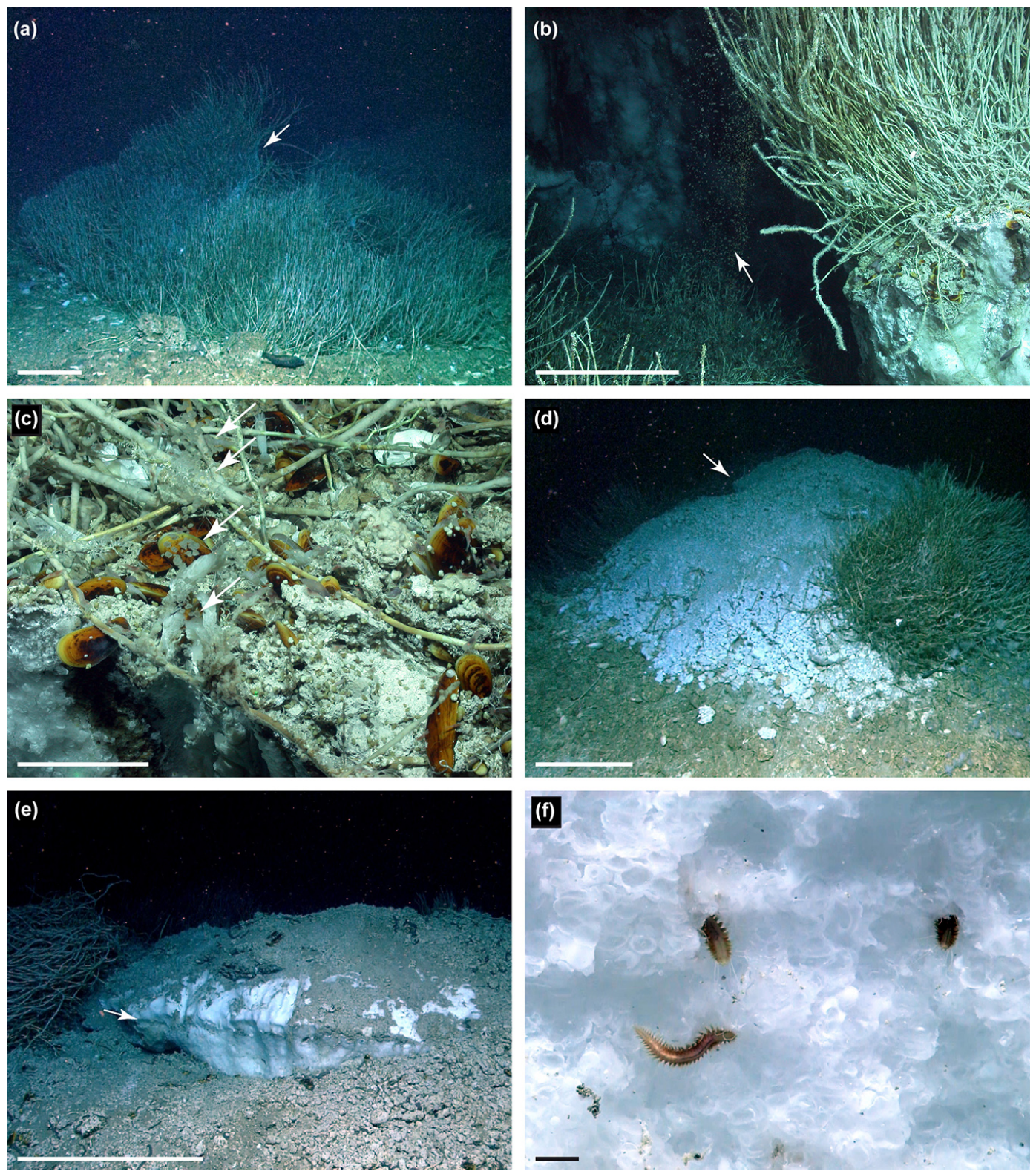

Figure 4. Seafloor images taken at Tsanyao Yang Knoll during ROV QUEST Dive 361. (a) Vestimentiferan tube worm bushes on a fractured mound (arrow). Scale bar $50 \mathrm{~cm}$ in foreground. (b) Gas bubble plume (arrow) rose through the gap of a fractured mound. Hydrates formed at the hanging walls. Scale bar $50 \mathrm{~cm}$. (c) Close-up of the mound surface with bubbles emitted into the water column (arrows) from the same spot. Gas hydrate occurred below a layer of authigenic carbonates with mytilids, vestimentifera, gastropods, and shrimps on top. Scale bar $10 \mathrm{~cm}$. (d) Mound with exposed gas hydrate (arrow) detailed in (e), (f). Scale bar $50 \mathrm{~cm}$. (e) Lens-shaped, exposed gas hydrate composed of bubble-fabric hydrate below and dense hydrate above the arrow. Scale bar $50 \mathrm{~cm}$. (f) Bubble-fabric hydrate inhabited by ice worms (cf. Hesiocaeca methanicola). Scale bar $1 \mathrm{~cm}$. All images courtesy of MARUM.

flows characterized by fragmented asphalts (Fig. 9b) toward the south and east. Noting significant sediment cover on older asphalts, we conjecture that the main asphalt flow represents the most recent stage of several flow events.

The bubble site is located on a ridge several metres high, formed of fragmented asphalts with soft sediments interspersed between the flow breccia. Gas bubbles escaped the seafloor and gas hydrates were present below a seafloor protrusion (Fig. 9c, d). Recovered sediments and rocks were heavily impregnated with oil. The fauna comprised mytilid bivalves including Bathymodiolus heckerae, B. brooksii, vestimentiferan tube worms, and a variety of organisms attracted by the seep system, such as Munidopsis geyeri and Alvinocaris muricola crustaceans (Gaytán-Caballero, 2009), 

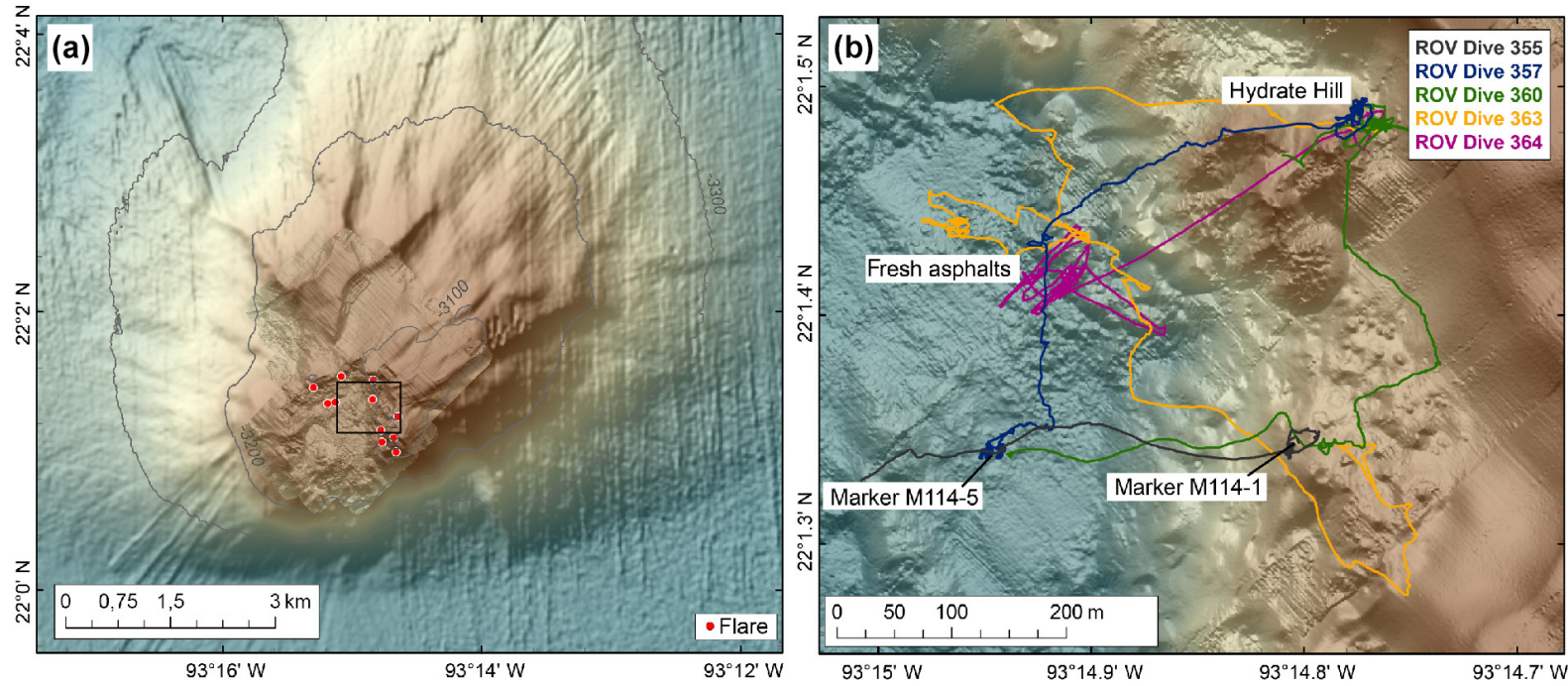

Figure 5. Maps of Mictlan Knoll (see Fig. 2 for location): (a) AUV-based bathymetry draped over ship-based bathymetry and positions of flares (red dots). The box defines the area illustrated in (b). (b) ROV QUEST dive tracks and main study sites plotted on AUV-based bathymetry.

gastropods, and sponges (Fig. 9d, e). A few metres away from the bubble site, oil drops or oil-coated bubbles were released from the seafloor (Fig. 9f) and dark orange, oil coated hydrate masses were exposed.

\subsubsection{Knoll 2000 (about $1850 \mathrm{~m}$ water depth)}

Knoll 2000 is an elongated feature next to a ridge with two faint flares that originated on the eastern flank of the knoll (Fig. 10). During an ROV dive, authigenic carbonates and dark-stained sediments with whitish patches, interpreted to be bacterial mats, were observed (Fig. 11e, f). Some of the authigenic carbonates were dark-stained and may have contained asphalt. The recovery of frenulate tube worms (Siboglinidae; Frenulata) in whitish-stained sediments (Fig. 11e) was noteworthy because species of this group were not observed at the other sites investigated in this study. However, because of their thin tubes, the tube worms were invisible for the camera systems during the dive. Gas bubble emissions were not observed during the one ROV dive to Knoll 2000.

\subsubsection{UNAM ridge (about $1230 \mathrm{~m}$ water depth)}

UNAM ridge is an approximately $500 \mathrm{~m}$-high ridge named after the Universidad Nacional Autónoma de México in appreciation of the collaborative effort to study the deep-water hydrocarbon seeps off Mexico. This was the shallowest site visited during this study. At least five flares were detected above the crest (Fig. 10). Two ROV dives revealed evidence for an active, albeit senescent seep system. Remarkably, soft corals and other hard-ground suspension feeders were found to settle on iron/manganese-stained carbonates and weathered asphalts (Fig. 11a). The occurrence of vestimentiferans tube worms was limited to a few bushes. Recumbent tube worms were dominant (Fig. 11b), which is generally considered as an indicator for a senescent community. Iron/manganese-stained carbonates were observed along with debris of mytilid shells (Fig. 11c). The most active seep site was situated on the side of a pockmark-like depression and comprised a relatively small bubble stream with only few specimens of living mytilid mussels on carbonates (Fig. 11d). On a small $20 \mathrm{~cm}$-high and $1 \mathrm{~m}$-wide sediment mound we observed a white, hydrate-like texture through a drape of sediment, suggesting the presence of gas hydrates but as we did not attempt any sampling, we cannot prove the occurrence of hydrates.

\subsection{Seafloor observations by camera sled}

In addition to the findings during M 114, camera sled deployments during the preceding cruises SO 174, M 67/2, and Chapopote III revealed evidence for the presence of asphalts and chemosynthetic communities at seven further knolls and ridges as summarized in Table 1 and Fig. 2. We realized that the identification of asphalts on the basis of images alone is ambiguous because the appearance of iron/manganesestained carbonates is similar to that of weathered asphalts as shown in Figs. 11a, c and 9b respectively. Nevertheless, the camera sled observations suggests that natural hydrocarbon seepage is widespread in the area of the Campeche Knolls.

\subsection{Gas composition and isotopes}

Hydrocarbons analysed from all gas bubble samples collected with the gas bubble sampler from Tsanyao Yang 

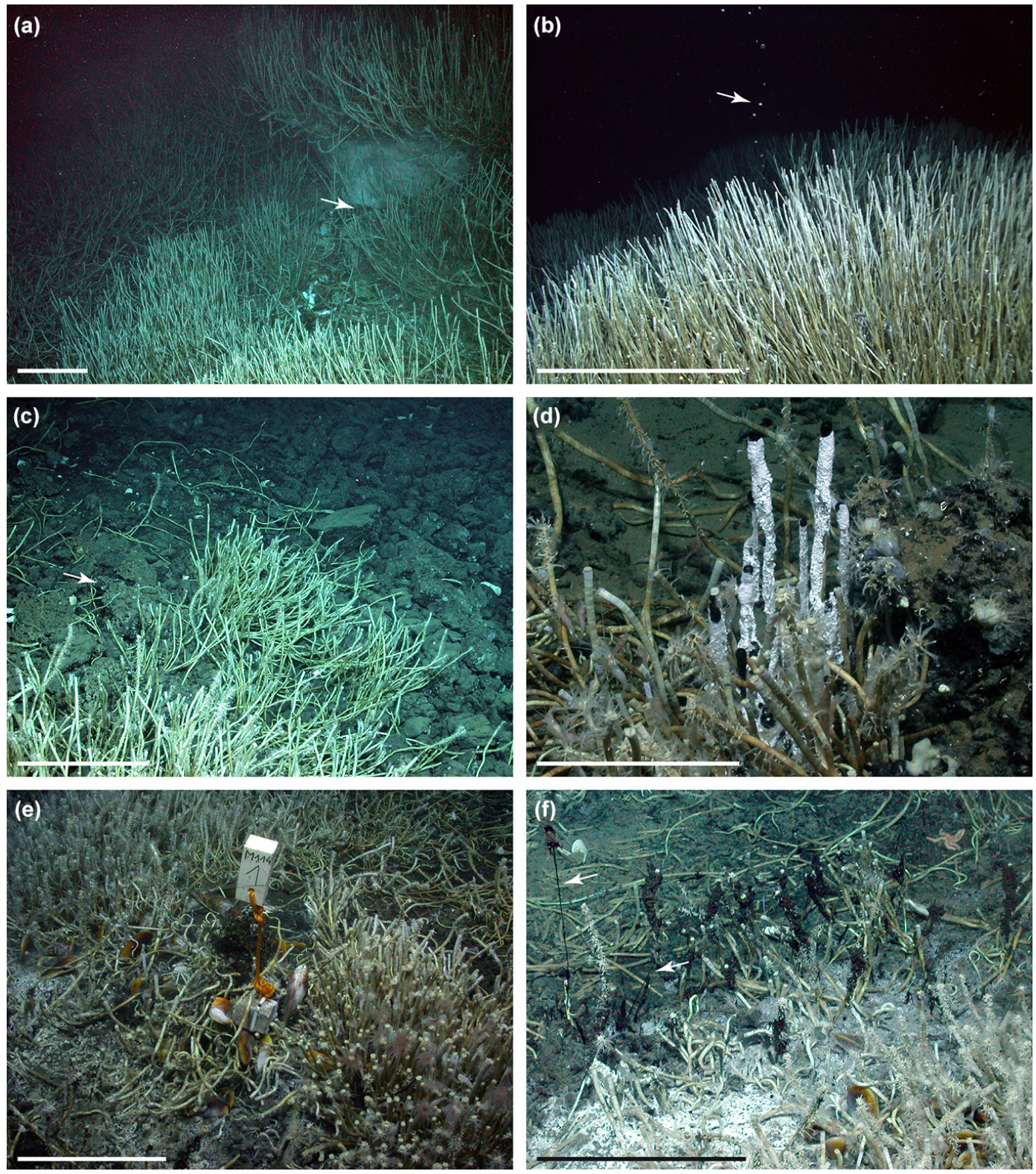

Figure 6. Seafloor images taken at Mictlan Knoll during ROV QUEST Dives 357 (a-d) and 360 (e, f). (a) Hydrate below overhanging vestimentiferan tube worms (arrow). Scale bar $50 \mathrm{~cm}$. (b) Gas bubble stream (arrow) rose through the hydrates and vestimentifera shown in (a). Scale bar $50 \mathrm{~cm}$. (c) Fragmented asphalt, authigenic carbonates (arrow), and vestimentifera. Scale bar $50 \mathrm{~cm}$. (d) Oil drops released through white-coated chimneys. Scale bar $20 \mathrm{~cm}$. (e) Flourishing ecosystem (mytilids, vestimentifera with epizoic suspension feeders, bacterial mats) next to oil-soaked sediments shown in (f). (f) Viscous oil drops emanated from the sediments leaving strands behind (arrow). Scale bar $20 \mathrm{~cm}$. All images courtesy of MARUM.

Knoll, Mictlan Knoll, Chapopote Knoll, and UNAM ridge were dominated by methane with a $\mathrm{C}_{1} / \mathrm{C}_{2}$ ratio varying between 14 and 185 (Fig. 12). The methane stable carbon isotope composition $\left(\delta^{13} \mathrm{C}-\mathrm{CH}_{4}\right)$ ranged between -45.1 and $-49.8 \%$ V-PDB. The oil drop sample revealed a relative $\mathrm{CH}_{4}$-depletion $\left(\mathrm{C}_{1} / \mathrm{C}_{2}=2\right)$ compared to the gas samples and the $\delta^{13} \mathrm{C}_{-} \mathrm{CH}_{4}$ value (-56.4\%o V-PDB) was more negative.

\section{Discussion}

\subsection{Natural hydrocarbon seepage in the Campeche Knolls}

The region of the Campeche Knolls shows evidence of abundant natural hydrocarbon seepage. This was already evident by the widespread presence of oil slicks at the sea surface (Williams et al., 2006; MacDonald et al., 2015; Suresh, 

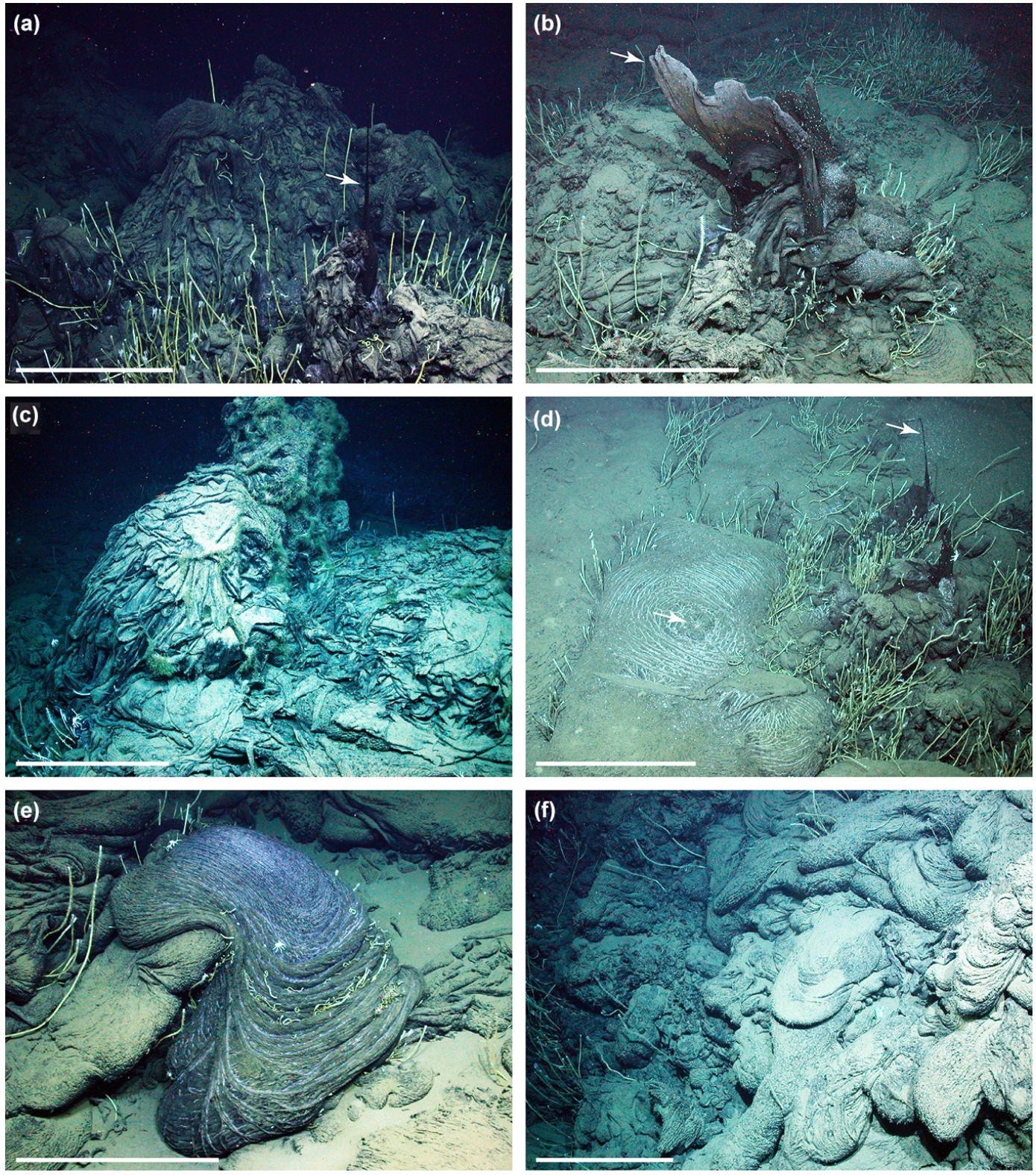

Figure 7. Seafloor images taken at Mictlan Knoll during ROV QUEST Dives 357 (b, c), 363 (a, e), and 364 (d-f). (a-c) Oil whips and sheets (arrows) floating in the water. Old whips and sheets apparently lost buoyancy and pile-up at the seafloor. (d-f) Flow structures of heavy oil. Scale bar all images $50 \mathrm{~cm}$. All images courtesy of MARUM.

2015). Knolls and ridges in Campeche Knolls are generally the seabed expressions of salt diapirism that causes hydrocarbons to accumulate and, eventually, to migrate though the sediments to the seafloor (Ding et al., 2008, 2010). More than 50 knolls and ridges in our study area exhibited single or multiple oil slick origins (Fig. 2), which suggests that they are as naturally prolific an oil seepage area as the salt province in the much better-studied northern Gulf of Mexico (GoM; e.g. MacDonald et al., 1993, 1996). In the Campeche Knolls, hydrocarbon seepage occurs in water depths down to about $3500 \mathrm{~m}$, which is considerably deeper than seeps discovered at the middle-lower continental slope in the northern GoM ( $\sim 2750$ to $\sim 970 \mathrm{~m}$; Roberts et al., 2010). Only the seeps at the Florida Escapment are located in comparable water depths at $3300 \mathrm{~m}$ (Paull et al., 1984; Cordes et al., 2007b).

While previous studies focused on Chapopote Knoll, we summarize in this study hydrocarbon seepage at the seafloor at five sites by ROV observations (including Chapopote Knoll) and, in addition, at seven sites by camera sled surveys at knolls and ridges (Fig. 2, Table 1). These sites range from depths around $1100 \mathrm{~m}$ in the south to $3420 \mathrm{~m}$ in the north of the study area. At all 12 sites we found evidence 

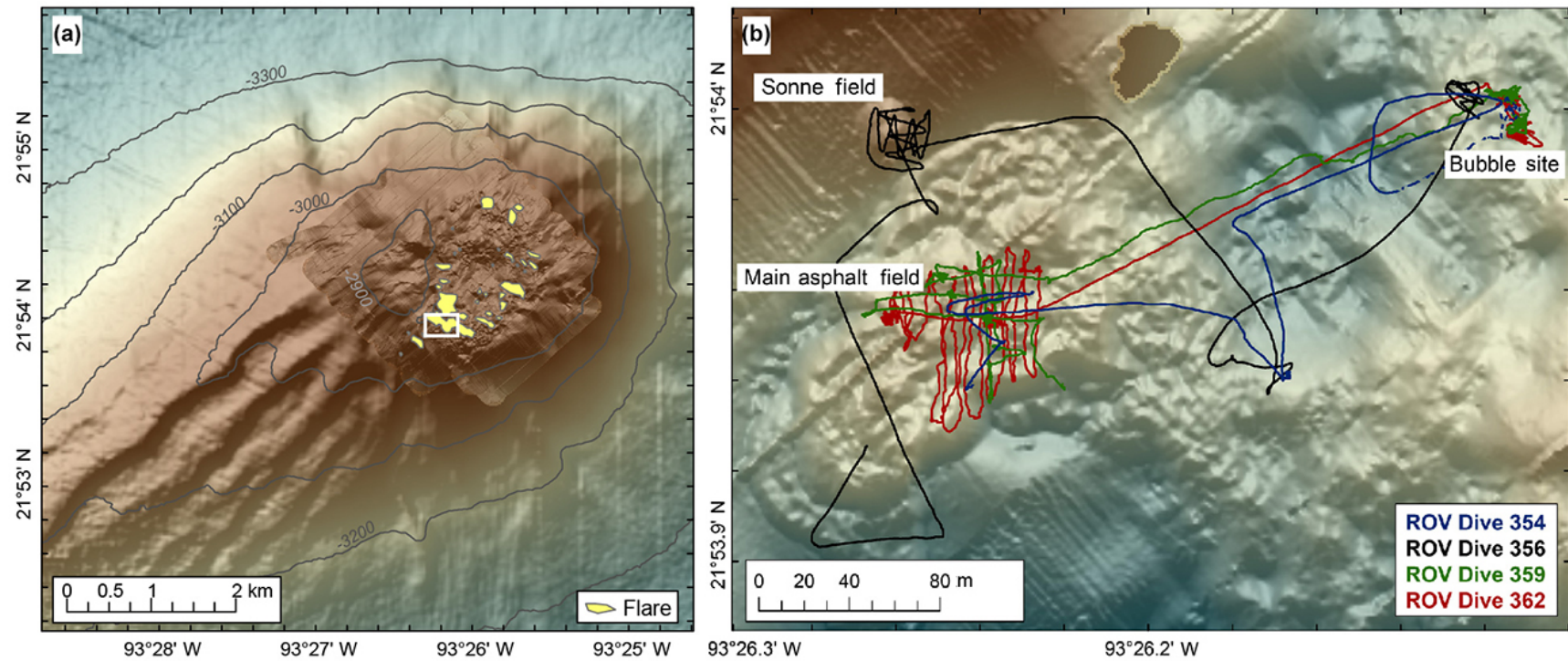

Figure 8. Maps of Chapopote Knoll (see Fig. 2 for location): (a) AUV-based bathymetry draped over ship-based bathymetry and areas of flares (yellow). The box shows the area in (b). (b) ROV QUEST dive tracks and main study sites plotted on AUV-based bathymetry.

of natural hydrocarbon seepage as indicated by the presence of chemoautotrophic communities, authigenic carbonates, or asphalt deposits, confirming that hydrocarbon seepage is a widespread process in the region of the Campeche Knolls. All of the 12 sites are located at the seafloor below sea surface oil slicks detected by satellite imagery (Williams et al., 2006). However, it should be noted that we only studied the seafloor close to oil slicks and that our method is biased, i.e. it does not provide a correlation between sea surface slicks and seafloor seepage.

Asphalt deposits were visually identified at seven sites (UNAM ridge, Chapopote Knoll and Mictlan Knoll; Sites 1, 3, 6, and 7; Table 1) and they probably also occur at four more sites (Knoll 2000, Sites 2, 4, and 5; Table 1). This clearly shows that seepage of heavy oil is an intrinsic property of the Campeche Knolls (Fig. 2). A possible reason for this is that the crude oil in the Campeche salt province is generally heavy (Magoon et al., 2001) in terms of API gravity (American Petroleum Institute gravity). For now we can only speculate on the mechanisms that lead to the expulsion and deposition of heavy oil on the seafloor, but we assume it is a combination of salt tectonic movements and high gas content that lead to the rise of this heavy oil to the seafloor, where it is then subjected to postdepositional weathering processes.

Out of the about ten sites with asphalt deposits at the seafloor, only three knolls (Chapopote Knoll, Mictlan Knoll, and Site 3; Table 1) exhibit features characteristic of asphalt volcanism (sensu MacDonald et al., 2004), which forms conical mounts with crater-like depressions and extensive hard substrata. The other sites either form ridges or the asphalts are associated with more complex morpholo- gies. Tsanyao Yang Knoll is a noteworthy exception, because we did not find indications for the presence of extensive asphalt deposits, although seepage of oil was observed. The fact that we did not observe large asphalt deposits might be the result of a too-limited survey effort. Alternatively, we speculate that the absence of asphalt deposits at Tsanyao Yang Knoll are related to its unique shape as it is the only flat-topped knoll analysed in this study: its morphology resembles that of passive-type salt diapirs (Ding et al., 2010), where salt intruding very close to the seafloor caused bending-up of hydrocarbon-bearing strata to the seabed. The structural framework of passive-type salt diapirs may not provide the necessary shallow hydrocarbon reservoir typical for the other knolls and ridges (Ding et al., 2008; 2010).

During our investigations it became clear that in most instances gas venting, oil seepage, and flows of heavy oil (leading to asphalt deposits) were temporally and spatially segregated. Oil and gas seepage occurred separately from asphalt occurrences (e.g. at Mictlan Knoll) but also through fractures in asphalts that probably act as conduits for gas/oil migration (e.g. at Hydrate Hill, Marker M114-5, Marker M114-1, and the bubble site at Chapopote). Different chemical compositions of oil and gas result in different manifestations at the seafloor, which we discuss in the following section.

\subsection{Geochemical characterization of gas, hydrate, and oil}

In order to characterize the origin of hydrocarbons generated in the deep subsurface below the emission sites, we analysed bubble-forming gas escaping the seafloor. Compared to the other hydrocarbon-containing organic substances discharged at the Campeche Knolls (e.g. oil, heavy oil), rapidly 

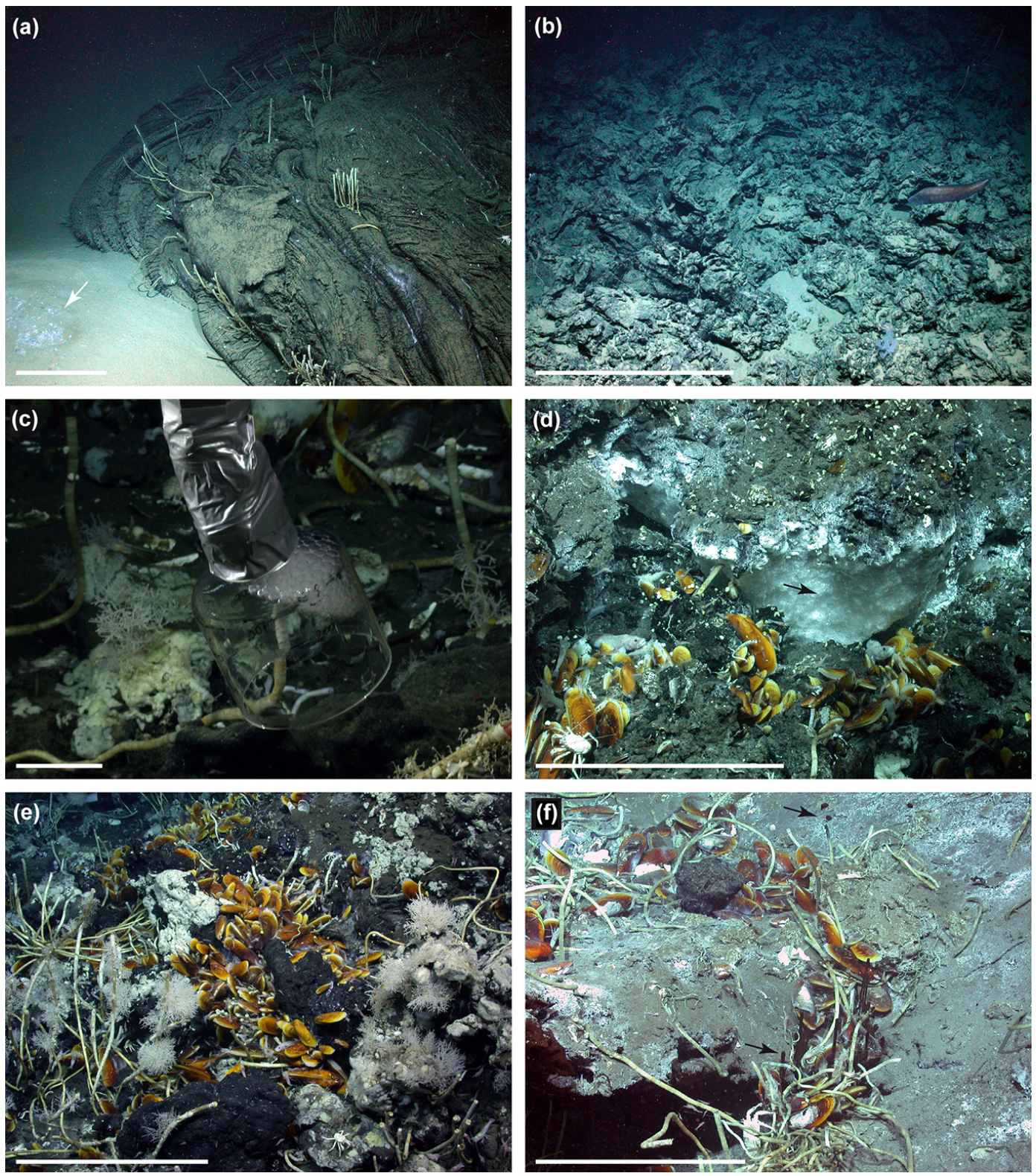

Figure 9. Seafloor images taken at Chapopote Knoll during ROV QUEST Dives 354 (c, e), 362 (a, f), and 365 (b, d). (a) Main asphalt field with vestimentifera bordering a bacterial mat (arrow) on soft sediments. Scale bar $50 \mathrm{~cm}$. (b) Older flow characterized by fragmented asphalt. Scale bar $50 \mathrm{~cm}$. (c) Catching hydrate-coated bubbles at the bubble site. Scale bar $10 \mathrm{~cm}$. (d) Gas hydrate outcrop (arrow) with mytilids, gastropods, galatheid crab. Note bubble fabric of exposed hydrate. Scale bar $50 \mathrm{~cm}$. (e) Sponges, hydrozoans, mytilids at the bubble site. Scale bar $50 \mathrm{~cm}$. (f) Oil drops and oil whips (arrows) close to the bubble site. Scale bar $50 \mathrm{~cm}$. All images courtesy of MARUM.

emitted vent gas is believed to be less affected by alteration in the course of upward migration in the sediment, thus it can provide an insight into the chemical characteristics of the subsurface reservoir of light hydrocarbons. Considering the molecular compositions of light hydrocarbons (expressed as $\mathrm{C}_{1} / \mathrm{C}_{2}$ ratios) and stable carbon isotopic signatures of methane $\left(\delta^{13} \mathrm{C}-\mathrm{CH}_{4}\right)$, most samples plot within or close to the empirical field proposed for a thermocatalytic origin (Fig. 12).
The variability of $\delta^{13} \mathrm{C}-\mathrm{CH}_{4}$ values in gas bubbles was noticeably small $\left(\Delta \delta^{13} \mathrm{C}-\mathrm{CH}_{4}=4.7 \%\right.$ V-PDB $)$, given the fact that sampling was conducted at four different knolls and ridges positioned at some tens to hundreds of kilometres distance from each other. In contrast, $\mathrm{C}_{1} / \mathrm{C}_{2}$ ratios appear to be more variable with the highest values determined for apparently pure gas bubbles from Hydrate Hill at Mictlan Knoll (185, GeoB19336-15) and lowest values for oil-coated bubbles at Tsanyao Yang Knoll (14, GeoB19337-2). A vari- 


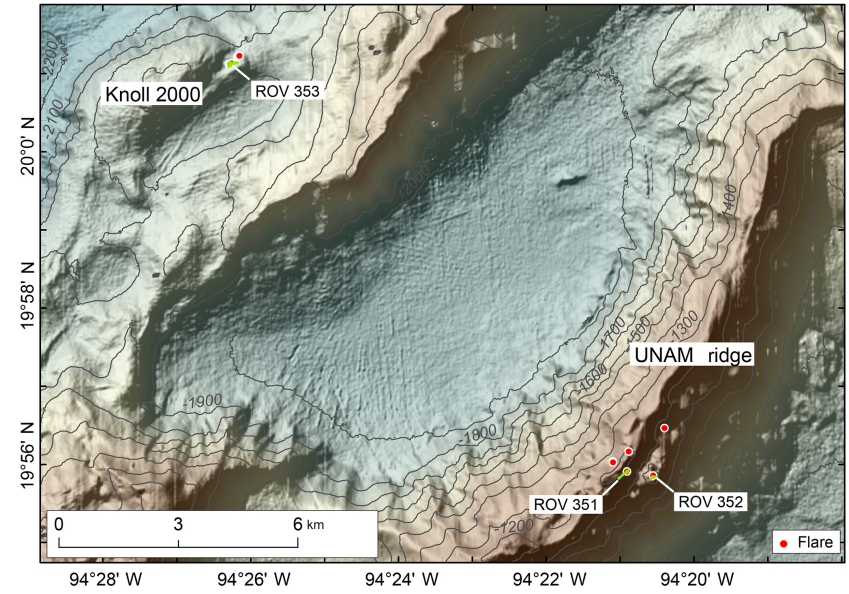

Figure 10. Ship-based bathymetry of Knoll 2000 and UNAM ridge (see Fig. 2 for location), locations of flares (red dots), and ROV QUEST dive tracks (green).

ety of possible post-genetic processes can affect the distributions of light hydrocarbons, e.g. abiotic molecular fractionation during migration (Leythaeuser et al., 1980), admixture with oil-derived components or secondary methane (Milkov and Dzou, 2007), and microbial oxidation of methane and non-methane hydrocarbons (Hoehler et al., 1994; Joye et al., 2004; Kniemeyer et al., 2007). However, the causes for the variations in $\mathrm{C}_{1} / \mathrm{C}_{2}$ ratios observed in this study remain unexplained.

Methane in the gas bubbles sampled during this study was enriched in ${ }^{13} \mathrm{C}$ relative to oil samples $\left({ }^{13} \mathrm{C}-\mathrm{CH}_{4}<-50.3 \%\right.$ o ), which were either collected during this study (one sample) or in the course of previous studies (Fig. 12) (MacDonald et al., 2004; Schubotz et al., 2011b). The variability in the $\delta^{13} \mathrm{C}_{-} \mathrm{CH}_{4}$ and $\mathrm{C}_{1} / \mathrm{C}_{2}$ ratios of the oil samples either reflects site-specific properties of the oil source or indicates alteration processes during migration to variable extents. More negative values $\delta^{13} \mathrm{C}_{-} \mathrm{CH}_{4}$ of the oil samples in general may result from admixture by microbial-produced ${ }^{13} \mathrm{C}$-depleted secondary methane from the oxidation of higher short-chained hydrocarbons at shallow sediment depth (Milkov and Dzou, 2007; Schubotz et al., 2011b).

We failed to sample gas hydrates during this study, but shallow hydrates were collected from two sites at Chapopote Knoll during previous investigations (MacDonald et al., 2004; Schubotz et al., 2011b). Hydrate-bound methane in these studies was depleted in ${ }^{13} \mathrm{C}$ by $>3 \%$ o compared to methane in bubbles collected in our study. It should be stressed that sampling was conducted in different years and not at exactly the same sites. Nevertheless, ${ }^{13} \mathrm{C}^{-} \mathrm{CH}_{4}$ differences between gas bubbles and hydrates within Chapopote Knoll are an interesting result, as hydrate deposits close to the seafloor are considered to form from gas bubbles (see below) without significant isotopic fractionation of methane (Bourry et al., 2009; Pape et al., 2010; Sassen et al., 2004).
The difference in $\delta^{13} \mathrm{C}$ of $>3 \%$ between methane in bubble streams and in shallow hydrates at Chapopote Knoll, therefore, suggests some contribution of microbial-generated methane to the hydrate.

\subsection{Gas venting, hydrate occurrence, and the vestimentifera-gas/hydrate habitat}

Gas emissions are integral parts of submarine seep systems in various geological settings worldwide but hydratecontaining mounds overgrown by dense vestimentiferan tube worm fields probably belonging to the genus Escarpia are, to our knowledge, unique to the Campeche Knolls. Massive hydrate deposits close to the seafloor are considered to result from gas bubble migration through the sediments (Haeckel et al., 2004; Smith et al., 2014). Part of the gas can be sequestered as gas hydrate at shallow sediment depths in case the crystallization force overcomes the effective overburden stress (Torres et al., 2004). Shallow hydrate deposits typically form a mounded topography of soft sediment at the seafloor as observed at Hydrate Ridge (Cascadia Margin; Suess et al., 2001; Sahling et al., 2002) and Bush Hill in the northern GoM (MacDonald et al., 1994). At Hydrate Ridge, intensive anaerobic oxidation of methane (AOM) in sediments overlying hydrates results in production of hydrogen sulfide that is consumed by sulfide-oxidizing bacteria that form mats draping the mounds (Boetius et al., 2000; Treude et al., 2003). Sulfate reduction coupled to the degradation of higher-order hydrocarbons brought along with oil propagating in the sediments was additionally proposed to occur in the northern GoM (Formolo et al., 2004; Joye et al., 2004).

In our study, we found vestimentiferan tube worms capping hydrate deposits, which has not been observed before in such a clear association. In order to illustrate the relevant processes, we illustrate the two different situations encountered at Tsanyao Yang Knoll and Mictlan Knoll in Fig. 13. At both knolls, gas bubbles percolated through the mounds and we propose that the continuous gas supply from below drives hydrate formation in the shallow subsurface. At Tsanyao Yang Knoll, hydrate formed as massive layers in the sediments within the mound (Fig. 4b), whereas for Mictlan Knoll we speculate that hydrates occupy voids between fragmented asphalt (Fig. 6a-c). In both cases, hydrates serve as methane reservoir (e.g. Sahling et al., 2002) from which methane and other short-chained hydrocarbons are constantly diffusing towards the overlaying seawater. We further propose that AOM dominates in the rhizosphere, which is a distinct $5-10 \mathrm{~cm}-$ thick layer consisting of the posterior tubes of the vestimentiferan tube worms. Vestimentiferan tube worms can release sulfate through their posterior tubes (Dattagupta et al., 2006, 2008) and we therefore suggest that the rhizosphere in particular is supporting AOM. Due to the fact that AOM efficiently produce alkalinity necessary for carbonate precipitation, we propose that vestimentifera in the southern GoM largely rely on sulfide produced by sulfate reduction coupled 

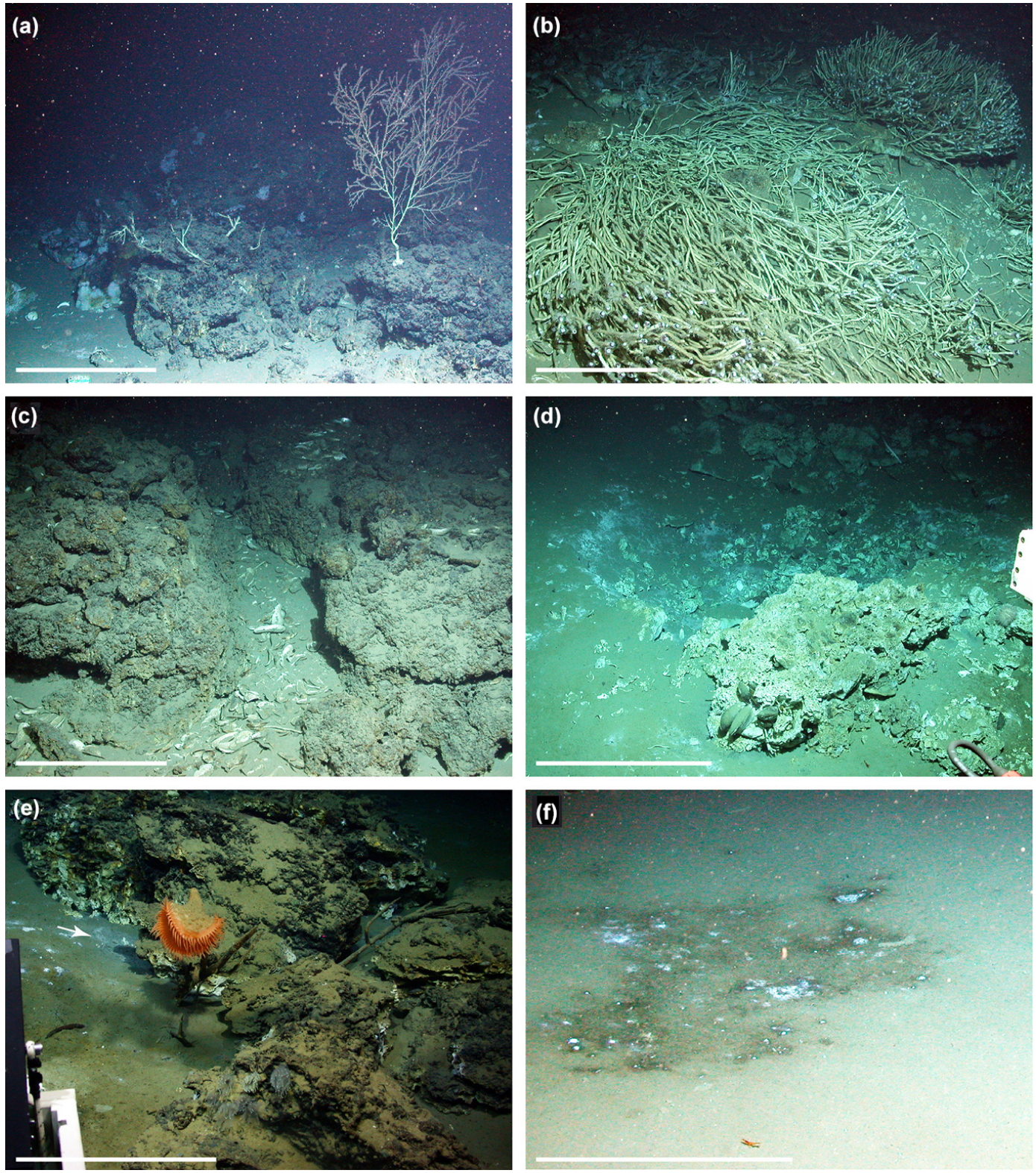

Figure 11. Seafloor images taken at UNAM ridge (a-d) and Knoll 2000 (e, f) during ROV QUEST dives 352 and 353 respectively. (a) Soft coral and other suspension feeders on iron-/manganese-stained authigenic carbonates. (b) Recumbent vestimentifera. (c) Authigenic carbonates and mytilid shells. (d) A few living mytilids attached to carbonates (foreground) and a 1 m-wide circular depression. (e) Frenulate tube worms were recovered from samples of whitish-stained sediments (arrow) next to carbonates inhabited by suspension feeders (Actinoscyphia sp., anemones, sponges). (f) Whitish patches at seafloor interpreted to be bacterial mats on dark-stained sediments. Scale bar all images $50 \mathrm{~cm}$. All images courtesy of MARUM.

to methane oxidation. This is further supported by the composition of the gas that forms the hydrate, which is dominated by methane (Fig. 12). The geochemistry in the southern GoM is in contrast to that for vestimentifera in the northern GoM, which rely on sulfide produced by sulfate-reduction coupled to methane oxidation and likely augmented by degeneration of organic carbon that may include higher hydrocarbons (e.g. Joye et al., 2004). We favour the concept that consid- ers the vestimentifera as ecosystem engineers (sensu Cordes et al., 2003, 2005) that play a pivotal role for this particular gas/hydrate habitat as they intensify chemical turnover processes within the rhizosphere, and the space at and in between the tubes provides habitat for numerous other seeptypical species. Moreover, the thick blanket of the rhizosphere shields gas hydrate from direct contact with seawater 


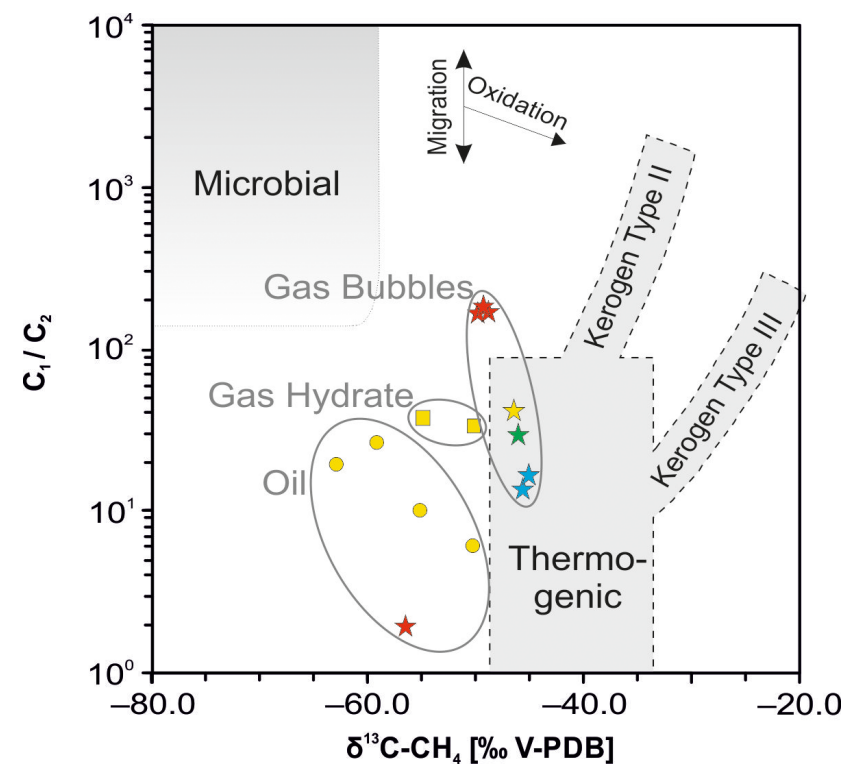

Figure 12. Molecular $\left(C_{1} / C_{2}\right)$ vs. stable $C$ isotopic composition of methane $\left(\delta^{13} \mathrm{C}-\mathrm{CH}_{4}\right)$ sampled by gas bubble sampler at Tsanyao Yang Knoll (blue), Mictlan Knoll (red), Chapopote Knoll (yellow), and UNAM ridge (green) and a single oil-associated gas sample (Mictlan Knoll) collected during this study with the GBS. Stars indicate samples analysed in this study, dots and squares are values according to results for methane in hydrates and oil collected during previous campaigns (MacDonald et al., 2004; Schubotz et al., 2011b). Classification according to the Bernard diagram, modified after Whiticar (1990). Gas samples studied herein are plotted close to the empirical field of thermogenic methane.

and may impede its dissolution, thereby preserving the driver of AOM.

With regard to our discovery of the vestimentiferagas/hydrate habitat, we attempted to characterize differences in environmental parameters in the Campeche Knolls and areas where bacterial mats drape soft sediments covering hydrates (MacDonald et al., 1994; Suess et al., 2001). First, seeps in the southern GoM occur at greater water depth $(\sim 3000 \mathrm{~m})$ than the hydrate mounds at Hydrate Ridge ( $\sim 780 \mathrm{~m})$ and at Bush Hill in the northern GoM $(\sim 540 \mathrm{~m})$. The higher pressure at greater water depth in conjunction with very vigorous gas bubble emission could lead to more voluminous and more rapid formation of gas hydrate close to the seafloor. In addition, the deep-water physical environment is more stable compared to at the upper slope, where temperature is higher and pressure changes are considerably larger (MacDonald et al., 1994, 2005). Further, with respect to the mature vestimentiferan communities and authigenic carbonates within the rhizosphere we speculate that gas seepage at our study sites was stable on extended timescales. Vestimentifera are considered to be long-living organisms, with estimated lifespans of 170-250 years for $2 \mathrm{~m}$-long species in the northern GoM (Bergquist et al., 2000; Cordes et al., 2007a). Although the vestimentiferan species present in the southern GoM probably belong to the genus Escarpia and are thus different from those in the northern GoM, it is possible that slow growth is a general characteristic of vestimentifera at seeps and that the vestimentifera observed in our study (with tube length of $\sim 2 \mathrm{~m}$ ) might be considerably old as well. Independent support comes from a modelling study that suggested timescales of 100 to 500 years for the formation of authigenic carbonate crust which are a few centimetres thick (Luff et al., 2004).

\subsection{Heavy oil flows leading to asphalt deposits and asphalt as habitat}

Our ROV-based observations revealed numerous examples for voluminous asphalt deposits at Chapopote Knoll and Mictlan Knoll. Their formation has been explained by a model proposed by Brüning et al. (2010), which takes the API gravity into account. Oil that floats in the water while still being attached to the seabed has an API gravity slighter higher than $10^{\circ} \mathrm{API}$, which corresponds to a density close to seawater. This places it at the boundary between heavy oil (10-12 to $\left.20^{\circ} \mathrm{API}\right)$ and very heavy oil $\left(<10-12^{\circ} \mathrm{API}\right)$, that are mobile and immobile at reservoir conditions respectively (Tissot and Welte, 1984). Oil whips and sheets were observed (Fig. 7a-c) indicating seepage of heavy oil that has slight positive buoyancy $\left(>10^{\circ} \mathrm{API}\right)$ but is sufficiently cohesive to remain attached to the point of extrusion. In contrast, the extensive asphalt deposits must have been negatively buoyant $\left(<10^{\circ} \mathrm{API}\right)$ when they exited because they clearly flowed at the seafloor (Figs. 7d-f, 9a). Incorporation of sediments into and accumulation of sediments onto flowing asphalts will also contribute to their negative buoyancy. Formation of asphalt deposits thus depends on the viscosity of the extruded heavy-to-very-heavy oil $\left(\sim 10^{\circ} \mathrm{API}\right)$ and the duration for which it is exposed to weathering processes at the seafloor that lead to a transition from mobile to immobile; i.e. the viscosity is high enough to allow the ascent through the sediment, but after emission at the seafloor, it rapidly becomes immobile, probably due an increase in viscosity due to the loss of volatile compounds.

In spite of this, additional possibly post-depositional processes lead to a decrease in bulk density, which can be deduced from observations at the main asphalt field at Chapopote Knoll. Pure gas hydrate, which typically exhibits a specific density less than seawater (ca. $0.9 \mathrm{~g} \mathrm{~cm}^{-3}$ ), was present below and within fresh asphalts (Schubotz et al., 2011b; Klapp et al., 2010a, b) and asphalt pieces floated up when extracted from an intact flow (Brüning et al., 2010). The elevated gas content might be explained by postdepositional hydrate formation and gas invasion into the pore space of the asphalts resulting from gas supply from below. However, with respect to the considerable difference in $\delta^{13} \mathrm{C}$ signatures between hydrate methane below the asphalts (-54.8\%o; Schubotz et al., 2011b) and the vent gas methane 

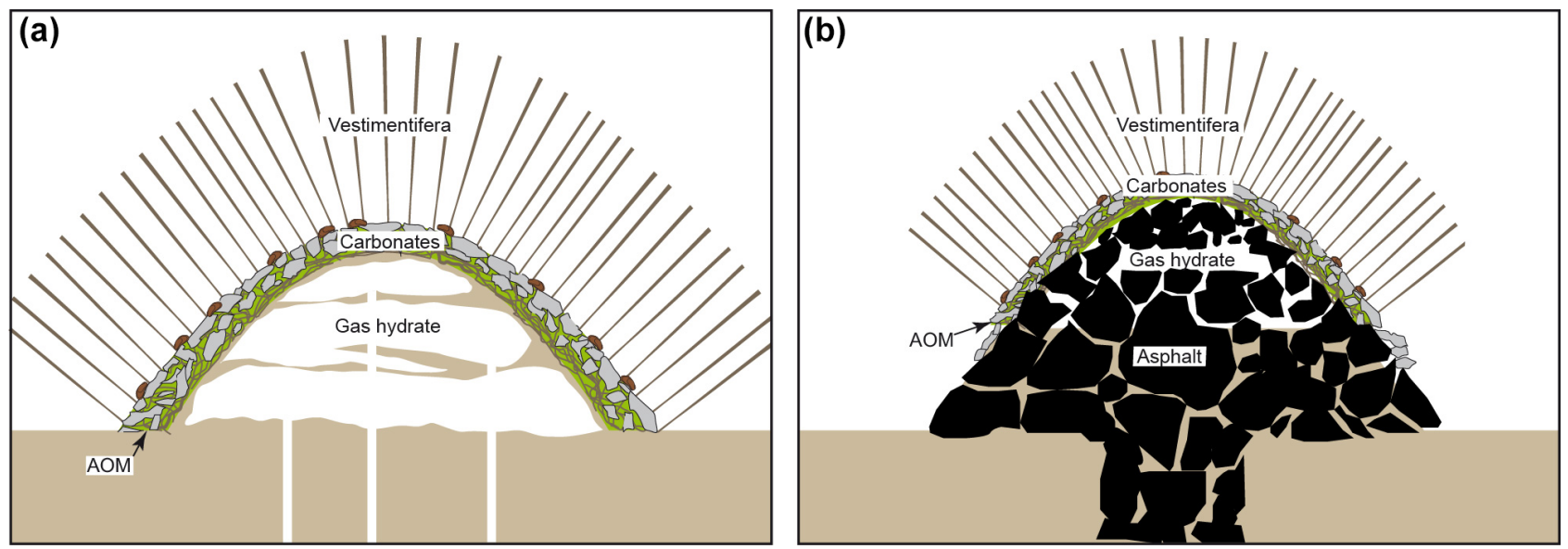

Figure 13. Sketch depicting the interpreted vestimentifera-gas/hydrate habitat encountered at (a) Tsanyao Yang Knoll and (b) Mictlan Knoll. Drawing not to scale. The mounds at Tsanyao Yang Knoll were a few metres wide whereas Hydrate Hill at Mictlan Knoll was about $30 \mathrm{~m}$ in diameter. AOM is anaerobic oxidation of methane (green).

(-46.5\% ; Fig. 12), it is unlikely that these gases share the same source. A possible interpretation for the more negative $\delta^{13} \mathrm{C}$-signature of hydrate-bound methane could be that microbial methane is produced in sufficient amounts in shallow, hydrocarbon-soaked sediments below or within the asphalts.

As we did not observe active extrusion of heavy oil during the ROV dives, discharge rates of heavy oil at the seafloor remain unknown but could possibly be in the range of weeks to years. The heavy oil apparently serves as energy source for chemosynthesis-based organisms like whitish bacterial mats and vestimentiferan tube worms that generally depend on the supply of reduced sulfur compounds (Hilario et al., 2011; Teske and Nelson, 2006). If the outflow of heavy oil is a slow process, chemosynthetic organisms may grow while the oil is still in motion. Alternatively, the chemosynthetic organism may settle after deposition. Chemosynthetic organisms may thrive on reduced sulfur compounds contained in the heavy oil or on sulfide produced during microbial oil degradation coupled to sulfate reduction (Schubotz et al., 2011b).

Based on their distribution at the seafloor exemplified in Fig. 7d and e, we propose that predominantly relatively young ejections, such as whips and sheets in the water column, and those in the central parts of asphalt flows, are populated by whitish bacterial mats. Moreover, the spatial extent of bacterial mats at the main asphalt field at Chapopote Knoll during this study in 2015 was very similar to that observed during its initial documentation in 2006 (Brüning et al., 2010), demonstrating considerable ecosystem stability over a decade. This is remarkable as we observed holothurians, galatheid crabs, and myriads of small crustaceans inferred to be grazing on the bacteria. This indicates a high primary production by chemosynthetic microbes. At more distal parts of the most recent asphalt deposits, bacterial mats were absent, while tube worms occurred nestling in fissures (Figs. 7e and 9a). Considering the relatively low growth rates of vestimentiferan tube worms (Bergquist et al., 2000), we propose that even the most recent asphalt deposits discovered in this study have already existed for decades. The ostensible absence of bacteria on asphalt surface and the presence of vestimentifera growing posteriorly into the substrate suggest that the sulfide source progresses towards deeper parts of the asphalts with time. This would be in line with our concept of successive stages being represented by bacteria and tube worms.

The most common asphalt deposits in our study were in an inert stage. It was devoid of any macro- or megafauna and ranged in terms of appearance from solid asphalt flows to partly or entirely fragmented asphalt deposits (e.g. Fig. 9b). We suggest that these asphalts no longer serve as habitats for chemosynthesis-based bacteria or tube worms because a greater portion of volatiles has already escaped to the water column. Furthermore, we point out that authigenic carbonates were virtually absent where fragmented asphalts occurred alone, i.e. without oil or gas seepage (Naehr et al., 2009). This observation suggests that microbial degradation of heavy oil does not produce sufficient alkalinity for authigenic carbonate formation. Based on our findings we may refer to the asphalt deposits without visible chemosynthetic fauna prevailing in the Campeche Knolls as being in an inert stage. Heterotrophic suspension feeders that are common in other regions with asphalt deposits (Weiland et al., 2008; Williamson et al., 2008; Valentine et al., 2010; Jones et al., 2014) were also absent at the inert stage at the Campeche Knolls. In our study area soft corals attached to asphalts were only found at the shallowest site investigated, UNAM ridge at $1230 \mathrm{~m}$ water depth (Fig. 11a). Therefore, the paucity of suspension feeders in the region of the Campeche Knolls might be caused by a limited food supply at the deep-water asphalt deposits, Mictlan Knoll and Chapopote Knoll (3420 to $2900 \mathrm{~m}$ water depth respectively). 
In contrast to seafloor asphalt deposits in other regions (Weiland et al., 2008; Williamson et al., 2008; Valentine et al., 2010; Jones et al., 2014), those in the Campeche Knolls are sourced by geologically recent emissions of heavy oil. However, given that lobate flow patterns are still discernible for asphalts in the Santa Barbara Basin 31 to $44 \mathrm{kyr}$ after seafloor deposition (Valentine et al., 2010), asphalt deposits sourced by emission of heavy oil in the Campeche Knolls may have existed for tens to probably hundreds of thousands of years while being fragmented and draped by sediments. The Campeche Knolls asphalts provide a natural laboratory for studying their more recent genesis as well as their alteration through time.

\subsection{Oil seepage and oil-soaked sediments as habitat}

Because oil seepage is an integral component of the hydrocarbon seepage system at the Campeche Knolls, as revealed by numerous oil slicks at the sea surface (Fig. 1), we concentrated on identifying oil seepage sites at the seafloor. In general, oil may rise as oil-coated gas bubbles or as oil drops (De Beukelaer et al., 2003; Leifer and MacDonald, 2003). Oily bubbles are difficult to identify visually during ascent through the water column, as they can appear as transparent as pure gas bubbles. Therefore, oil might have been a significant component of the observed gas bubble streams. Only in a few instances, the coating of gas bubbles was dark and the hydrate forming from the bubbles was dark stained. In contrast, a release of oil drops was clearly observed and occurred in association with two different seafloor manifestations: white-coated chimneys (Fig. 6d) and oil-soaked sediments inhabited by Bathymodiolus heckerae (Fig. 9f). These observations demonstrate that a seep system of oil exists next to a seep system of heavy oil leading to asphalt deposits. Seepage of oil was associated with old asphalt deposits (sediment-covered asphalt mounds and fragmented asphalt pieces) at three sites (Marker M114-1 and M115-5 at Mictlan Knoll; bubble site at Chapopote Knoll), suggesting that the oil migrated through the sediments along pre-existing pathways.

At Chapopote Knoll and Mictlan Knoll biological communities were physically exposed to oil (Figs. 6f, 9f). As found in the northern GoM, degradation of oil-derived components in sediments, like non-methane hydrocarbons, can be performed by sulfate-reducing bacteria (belonging to the $\delta$ proteobacteria group) while producing hydrogen sulfide (e.g. Joye et al., 2004; Kniemeyer et al., 2007). This is used as an energy source for chemosynthesis-based organisms such as mat-forming, sulfide-oxidizing bacteria, and vestimentifera living in symbiosis with chemosynthetic bacteria. The two mytilid species studied in our area harbour symbionts that are capable of oxidizing sulfides as well as methane (Raggi et al., 2013). In addition, the mussel Bathymodiolus heckerae from the bubble site at Chapopote Knoll evidenced a unique symbiosis with a proteobacterium of the genus Cycloclasti- cus, which is supposed to degrade hydrocarbons (Raggi et al., 2013). This symbiosis is unique to that site where the animals are virtually bathed in oil.

\section{Summary}

Natural oil seepage is inherent to the Campeche Knolls, as revealed by our new findings obtained during cruise M114 in 2015 , and by a reanalyses of seafloor images gathered during previous cruises. Unique to the Campeche Knolls is the widespread occurrence of asphalt deposits, which was definitely confirmed at seven sites. The flow structures of heavy oil encountered at Chapopote Knoll and Mictlan Knoll are noteworthy, as they represent more recent asphalt deposits compared to those described from other continental margin settings. The recently discharged asphalts sustain chemosynthetic organisms such as bacterial mats and vestimentifera as well as a suite of heterotrophic organisms that warrant further taxonomic studies. Based on our preliminary observations, and in contrast to the asphalt deposits at other continental margins, those at the deeper Campeche Knolls (> 2900 m water depth) are generally not utilized by sessile, filter-feeding organisms that attach to hard substrates.

Seepage of oil and gas bubbles co-occurs next to and through the asphalt deposits. Most intriguing was our finding of vigorous gas bubble streams forming hydrate mounds (Tsanyao Yang Knoll) or percolating through old, fragmented asphalts leading to hydrate precipitation in the voids between the asphalt breccia (Mictlan Knoll). The hydrates likely serve as a shallow methane reservoir underlying dense communities of vestimentiferan tube worms, which then act as ecosystem engineers, facilitating AOM, and preserving the hydrate. We further suggest that in the tube worms rhizosphere, intense microbially mediated turnover processes are probably taking place, which facilitated the precipitation of authigenic carbonates. Our observation of the closely associated hydrate and vestimentiferan tube worm is unparalleled, but this relationship and the involved biogeochemical processes could also be relevant in other hydrocarbon settings with shallow hydrate deposits. The healthy-appearing vestimentifera growing on hydrate suggest considerable stability of these habitats over extended time spans, required for establishment of the slow-growing vestimentifera and formation of authigenic carbonates.

Oil drops escaped the seafloor through small chimney-like structures or, together with gas bubbles, through a mixture of fragmented, old asphalt and sediments. In the latter case, sediments were heavily impregnated by oil. The seep-associated communities appeared very diverse, with two chemosynthetic mussel species and various other heterotrophic organisms. 


\section{Data availability}

The data will be freely accessible through the world data center PANGAEA after publishing the major results in peerreviewed publications. The data will become available at: https://doi.pangaea.de/10.1594/PANGAEA.860373.

\section{The Supplement related to this article is available online at doi:10.5194/bg-13-4491-2016-supplement.}

Author contributions. Maxim Rubin Blum, Gerhard Bohrmann, Christian Borowski, Chieh-Wei Hsu, Markus Loher, Ian MacDonald, Yann Marcon, Miriam Römer, Heiko Sahling, Florence Schubotz, Daniel Smrzka, and Gunter Wegener conducted the ROV dives as scientific advisors on which this present study is largely based on. Chieh-Wei Hsu, Markus Loher, and Miriam Römer detected the gas emissions by hydroacoustic means. Thomas Pape analysed the gas. Adriana Gaytán-Caballero assisted in taxonomic determination of fauna at sea. Elva Escobar-Briones supported the application procedure to acquire the Mexican research permission and supervised the participation of three Mexican scientists and students in the cruise. Heiko Sahling prepared the manuscript with contributions of all co-authors.

Acknowledgements. We are grateful to the Mexican authorities for granting permission to conduct the research in the southern Gulf of Mexico (permission of DGOPA: 02540/14 from 5 November 2014). We thank the master and crew of R/V Meteor for their highly professional assistance at sea. Thanks to MARUM AUV SEAL 5000 and ROV QUEST $4000 \mathrm{~m}$ teams for providing and handling of the indispensable equipment at sea. Various people have contributed to the successful cruise, we namely thank Monika Breitzke, Stefanie Buchheister, Christian Ferreira, Patrizia Geprägs, Jan-Derk Groeneveld, Elvira Jiménez Guadarrama, Ingo Klaucke, Sven Klüber, Esmeralda Morales Dominguez, Gopika Suresh, Marta Torres, Monika Wiebe, Paul Wintersteller, and Jennifer Zwicker. We thank three anonymous reviewers and Daniel Orange for their constructive comments that improved the manuscript. The cruise was core funded by the German Research Foundation (DFG - Deutsche Forschungsgemeinschaft) through the cruise proposal "Hydrocarbons in the southern Gulf of Mexico". Additional support was provided through the DFG-Research Center/Excellence Cluster "The Ocean in the Earth System".

The article processing charges for this open-access publication were covered by the University of Bremen.

Edited by: H. Niemann

Reviewed by: three anonymous referees

\section{References}

Bergquist, D. C., Williams, F. M., and Fisher, C. R.: Longevity record for deep-sea invertebrate, Nature, 403, 499-500, 2000.
Boetius, A., Ravenschlag, K., Schubert, C. J., Rickert, D., Widdel, F., Gieseke, A., Amann, R., Jørgensen, B. B., Witte, U., and Pfannkuche, O.: A marine microbial consortium apparently mediating anaerobic oxidation of methane, Nature, 407, 623-626, 2000 .

Bohrmann, G. and Schenk, S.: RV Sonne, Cruise report SO 174, OTEGA II: (Lotus-Omega-Mumm), Balboa-Corpus ChristiMiami, 1 October-12 November 2003, 117 pp., 2004.

Bohrmann, G., Spiess, V., and cruise participants: Report and preliminary results of R/V Meteor Cruise M67/2a and 2b, Balboa Tampico - Bridgetown, 15 March-24 April 2006, Fluid seepage in the Gulf of Mexico., Berichte Fachbereich Geowissenschaften, Universität Bremen, Bremen, 263, 119 pp., 2008.

Bourry, C., Chazallon, B., Charlou, J. L., Donval, J. P., Ruffine, L., Henry, P., Geli, L., and Cagatay, M. N.: Free gas and gas hydrates from the Sea of Marmara, Turkey, Chemical and strucural characterization, Chem. Geol., 264, 192-206, 2009.

Brüning, M., Sahling, H., MacDonald, I. R., Ding, F., and Bohrmann, G.: Origin, distribution, and alteration of asphalts at Chapopote Knoll, Southern Gulf of Mexico, Mar. Petrol. Geol., 27, 1093-1106, 2010.

Bryant, R. B., Lugo, J., Córdova, C., and Salvador, A.: Physiography and bathymetry, in: The Geology of Northern America, The Gulf of Mexico Basin, edited by: Salvador, A., Geological Society of America, Boulder, Colorado, 1991.

Caress, D. W. and Cheyes, D. N.: MB-System Seafloor Mapping Software, http://www.mbari.org/data/mbsystem/, last access: 31 January 2014.

Cordes, E. E., Bergquist, D. C., Shea, K., and Fisher, C. R.: Hydrogen sulphide demand of long-lived vestimentiferan tubeworm aggregations modifies the chemical environment at deep-sea hydrocarbon seeps, Ecol. Lett., 6, 212-219, 2003.

Cordes, E. E., Hourdez, S., Predmore, B. L., Redding, M. L., and Fisher, C. R.: Succession of hydrocarbon seep communities associated with the long-lived foundation species Lamellibrachia luymesi, Mar. Ecol. Prog. Ser., 305, 17-29, 2005.

Cordes, E. E., Bergquist, D. C., Redding, M. L., and Fisher, C. R.: Patterns of growth in cold-seep vestimenferans including Seepiophila jonesi: a second species of long-lived tubeworm, Mar Ecol., 28, 160-168, 2007a.

Cordes, E. E., Carney, S. L., Hourdez, S., Carney, R. S., Brooks, J. M., and Fisher, C. R.: Cold seeps of the deep Gulf of Mexico: Community structure and biogeographic comparison to Atlantic equatorial belt seep communities, Deep-Sea Res. Pt. I, 54, 637653, 2007b.

Cruz-Mercado, M. Á., Flores-Zamora, J. C., León-Ramirez, R., López-Céspedes, H. G., Peterson-Rodríguez, R. H., ReyesTovar, E., Sánchez-Rivera, R. S., and Barrera-Gonzáles, D.: Salt provinces in the Mexican portion of the Gulf of Mexico - structural characterization and evolutionary model, Gulf Coast Assoc. Geol. Soc. Trans., 61, 93-103, 2011.

Dattagupta, S., Miles, L. L., Barnabei, M. S., and Fisher, C. R.: The hydrocarbon seep tubeworm Lamellibrachia luymesi primarily eliminates sulfate and hydrogen ions across its roots to conserve energy and ensure sulfide supply, J. Exp. Biol., 209, 3795-3805, 2006.

Dattagupta, S., Arthur, M. A., and Fisher, C. R.: Modification of sediment geochemistry by the hydrocarbon seep tubeworm 
Lamellibrachia luymesi: A combined empirical and modeling approach, Geochim. Cosmochim. Ac., 72, 2298-2315, 2008.

De Beukelaer, S. M., MacDonald, I. R., Guinnasso, N. L., and Murray, J. A.: Distinct side-scan sonar, RADARSAT SAR, and acoustic profiler signatures of gas and oil seeps on the Gulf of Mexico slope, Geo-Mar. Lett., 23, 177-186, 2003.

Ding, F., Spiess, V., Brüning, M., Fekete, N., Keil, H., and Bohrmann, G.: A conceptual model for hydrocarbon accumulation and seepage processors around Chapopote asphalt site, southern Gulf of Mexico: From high resolution seismic point of view, J. Geophys. Res., 113, B08404, doi:10.1029/2007JB005484, 2008.

Ding, F., Spiess, V., MacDonald, I. R., Brüning, M., Fekete, N., and Bohrmann, G.: Shallow sediment deformation styles in northwest Campeche Knolls, Gulf of Mexico and their controls on the occurrence of hydrocarbon seepage, Mar. Petrol. Geol., 27, 959972, 2010.

Formolo, M. J., Lyons, T. W., Zhang, C., Kelley, C., Sassen, R., Horita, J., and Cole, D. R.: Quantifying carbon sources in the formation of authigenic carbonates at gas hydrate sites in the Gulf of Mexico, Chem. Geol., 205, 253-264, 2004.

Garrison, L. E. and Martin, R. G. J.: Geologic structure in the Gulf of Mexico, US Government Printing Office, Washington, DC, 85 pp., 1973.

Gaytán-Caballero, A.: Munidopsis geyeri Pequegnat \& Pequegnat, 1970 asociado al volcán de asfalto (sur del Golfo de México) y su vinculación con las poblaciones del Atlántico, master thesis, Universidad Nacional Autónoma de México, Mexico City, 146 pp., 2009.

Greinert, J., Artemov, Y., Egorov, V., Debatist, M., and McGinnis, D.: 1300 -m-high rising bubbles from mud volcanoes at $2080 \mathrm{~m}$ in the Black Sea: Hydroacoustic characteristics and temporal variability, Earth Planet. Sci. Lett., 244, 1-15, 2006.

Haeckel, M., Suess, E., Wallmann, K., and Rickert, D.: Rising methane gas bubbles form massive hydrate layers at the seafloor, Geochim. Cosmochim. Ac., 68, 4335-4345, 2004.

Hilario, A., Capa, M., Dahlgren, T. G., Halanych, K. M., Little, C. T., Thornhill, D. J., Verna, C., and Glover, A. G.: New perspectives on the ecology and evolution of siboglinid tubeworms, PLoS One, 6, e16309, doi:10.1371/journal.pone.0016309, 2011.

Hoehler, T. M., Alperin, M. J., Albert, D. B., and Martens, C. S.: Field and laboratory studies of methane oxidation in an anoxic marine sediment: evidence for methanogenic-sulfate reducer consortium, Global Biogeochem. Cy., 8, 451-463, 1994.

Jones, D. O. B., Walls, A., Clare, M., Fiske, M. S., Weiland, R. J., O'Brien, R., and Touzel, D. F.: Asphalt mounds and associated biota on the Angolan margin, Deep-Sea Res. Pt. I, 94, 124-136, 2014.

Joye, S. B., Boetius, A., Orcutt, B. N., Montoya, J. P., Schulz, H. N., Erickson, M. J., and Lugo, S. K.: The anaerobic oxidation of methane and sulfate reduction in sediments from Gulf of Mexico cold seeps, Chem. Geol., 205, 219-238, 2004.

Klapp, S. A., Bohrmann, G., Kuhs, W. F., Mangir Murshed, M., Pape, T., Klein, H., Techmer, K. S., Heeschen, K. U., and Abegg, F.: Microstructures of structure I and II gas hydrates from the Gulf of Mexico, Mar. Petrol. Geol., 27, 116-125, 2010a.

Klapp, S. A., Murshed, M. M., Pape, T., Klein, H., Bohrmann, G., Brewer, P. G., and Kuhs, W. F.: Mixed gas hydrate structures at the Chapopote Knoll, southern Gulf of Mexico, Earth Planet. Sci. Lett., 299, 207-217, 2010b.

Kniemeyer, O., Musat, F., Sievert, S. M., Knittel, K., Wilkes, H., Blumenberg, M., Michaelis, W., Classen, A., Bolm, C., Joye, S. B., and Widdel, F.: Anaerobic oxidation of short-chain hydrocarbons by marine sulphate-reducing bacteria, Nature, 449, 898902, 2007.

Leifer, I. and MacDonald, I.: Dynamics of the gas flux from shallow gas hydrate deposits: interaction between oily hydrate bubbles and the oceanic environment, Earth Planet. Sci. Lett., 210, 411424, 2003.

Leythaeuser, D., Schaefer, R. G., and Yukler, A.: Diffusion of light hydrocarbons through near-surface rocks, Nature, 284, 522-525, 1980.

Luff, R., Wallmann, K., and Aloisi, G.: Numerical modeling of carbonate crust formation at cold vent sites: Significance for fluid and methane budgets and chemosynthetic biological communities, Earth Planet. Sci. Lett., 221, 337-353, 2004.

MacDonald, I., Bender, L., Vardaro, M., Bernard, B., and Brooks, J.: Thermal and visual time-series at a seafloor gas hydrate deposit on the Gulf of Mexico slope, Earth Planet. Sci. Lett., 233, 45-59, 2005.

MacDonald, I. R., Guinasso jr., N. L., Ackleson, S. G., Amos, J. F., R., D., Sassen, R., and Brooks, J. M.: Natural oil slicks in the Gulf of Mexico visible from space, J. Geophys. Res., 98, 1635116364, 1993.

MacDonald, I. R., N. L. Guinasso, J., Sassen, R., Brooks, J. M., Lee, L., and Scott, K. T.: Gas hydrate that breaches the sea floor on the continental slope of the Gulf of Mexico, Geology, 22, 699-702, 1994.

MacDonald, I. R., Reilly Jr., J. F., Best, S. E., Venkataramaiah, R., Sassen, R., and Guinasso Jr., N. L.: Remote sensing inventory of active oil seeps and chemosynthetic communities in the northern Gulf of Mexico, in: Hydrocarbon migration and its nearsurface expression, edited by: Schumacher, D. and Abrams, M. A., American Association of Petroleum Geologists, 27-37, 1996.

MacDonald, I. R., Bohrmann, G., Escobar, E., Abegg, F., Blanchon, P., Blinova, V., Brückmann, W., Drews, M., Eisenhauer, A., Han, X., Heeschen, K., Meier, F., Mortera, C., Naehr, T., Orcutt, B., Bernard, B., Brooks, J., and de Farágo, M.: Asphalt volcanism and chemosynthetic life in the Campeche Knolls, Gulf of Mexico, Science, 304, 999-1002, 2004.

MacDonald, I. R., Escobar, E., Naehr, T., Joye, S., and Spiess, V.: The asphalt ecosystem of the Gulf of Mexico: Results from the Chapopte III Cruise, Fall Meet. Suppl., Abstract B43E-1660, 2007.

MacDonald, I. R., Garcia-Pineda, O., Beet, A., Daneshgar Asl, S., Feng, L., Graettinger, G., French-McCay, D., Holmes, J., Hu, C., Huffer, F., Leifer, I., Muller-Karger, F., Solow, A., Silva, M., and Swayze, G.: Natural and unnatural oil slicks in the Gulf of Mexico, J. Geophys. Res.-Ocean., 120, 8364-8380, 2015.

Magoon, L. B., Hudson, T. L., and Cook, H. E.: Pimienta-Tamabra (!) - A giant supercharged petroleum system in the southern Gulf of Mexico, onshore and offshore Mexico, in: The western Gulf of Mexico basin: Tectonics, sedimentary basins, and petroleum systems, edited by: Bartolini, C., Biuffler, R. T., and Cantú-Chapa, A., AAPG Memoir, 75, 83-125, 2001. 
Milkov, A. V. and Dzou, L.: Geochemical evidence of secondary microbial methane from very slight biodegradation of undersaturated oils in a deep hot reservoir, Geology, 35, 455-458, 2007.

Naehr, T. H., Birgel, D., Bohrmann, G., MacDonald, I. R., and Kasten, S.: Biogeochemical controls on authigenic carbonate formation at the Chapopote "asphalt volcano", Bay of Campeche, Chem. Geol., 266, 390-402, 2009.

Nikolovska, A., Sahling, H., and Bohrmann, G.: Hydroacoustic methodology for detection, localization, and quantification of gas bubbles rising from the seafloor at gas seeps from the Black Sea, Geochem. Geophys. Geosys., 9, Q10010, doi:10.1029/2008GC002118, 2008.

Pape, T., Bahr, A., Rethemeyer, J., Kessler, J. D., Sahling, H., Hinrichs, K.-U., Klapp, S. A., Reeburgh, W. S., and Bohrmann, G.: Molecular and isotopic partitioning of low-molecular-weight hydrocarbons during migration and gas hydrate precipitation in deposits of a high-flux seepage site, Chem. Geol., 269, 350-363, 2010.

Paull, C. K., Hecker, B., Commeau, R., Freeman-Lynde, R. P., Neumann, C., Corso, W. P., Golubic, S., Hook, J. E., Sikes, E., and Curray, J.: Biological communities at the Florida Escarpment resemble hydrothermal vent taxa, Science, 226, 965-967, 1984.

Raggi, L., Schubotz, F., Hinrichs, K. U., Dubilier, N., and Petersen, J. M.: Bacterial symbionts of Bathymodiolus mussels and Escarpia tubeworms from Chapopote, an asphalt seep in the southern Gulf of Mexico, Environ. Microbiol., 15, 1969-1987, 2013.

Roberts, H. H., Shedd, W., and Hunt Jr, J.: Dive site geology: DSV ALVIN (2006) and ROV JASON II (2007) dives to the middlelower continental slope, northern Gulf of Mexico, Deep-Sea Res. Pt. II, 57, 1837-1858, 2010.

Römer, M., Sahling, H., Pape, T., Bahr, A., Feseker, T., Wintersteller, P., and Bohrmann, G.: Geological control and magnitude of methane ebullition from a high-flux seep area in the Black Sea-the Kerch seep area, Mar. Geol., 319-322, 57-74, 2012.

Sahling, H., Rickert, D., Lee, R. W., Linke, P., and Suess, E.: Macrofaunal community structure and sulfide flux at gas hydrate deposits from the Cascadia convergent margin, NE Pacific, Mar. Ecol. Prog. Ser., 231, 121-138, 2002.

Sahling, H. and Bohrmann, G.: Seafloor images along 9 ROV profiles during METEOR cruise M114/2, unpublished dataset \#860373, available at: https://doi.pangaea.de/10.1594/ PANGAEA.860373, last access: 10 August 2016.

Salvador, A. (Ed.): The Gulf of Mexico basin, Geology of North America, Geological Society of America, Boulder, Colorado, 568 pp., 1991.

Sánchez-Rivera, R. S., Cruz-Mercado, M. Á., Reyes-Tovar, E., López-Céspedes, H. G., Peterson-Rodriguez, R. H., FloresZamora, J. C., Ramirez, R. L., and Barrera-Gonzáles, D.: Tectonic evolution of the South Gulf Salt Province in the Gulf of Mexico, Gulf Coast Assoc. Geol. Soc. Trans., 61, 421-427, 2011.

Sassen, R., Roberts, H. H., Carney, R., Milkov, A. V., DeFreitas, D. A., Lanoil, B., and Zhang, C.: Free hydrocarbon gas, gas hydrate, and authigenic minerals in chemosynthetic communities of the northern Gulf of Mexico continental slope: relation to microbial processes, Chem. Geol., 205, 195-217, 2004.

Scholz-Böttcher, B. M., Ahlf, S., Vazquez-Gutierrez, F., and Rullkötter, J.: Sources of hydrocarbon pollution in surface sediments of the Campeche Sound, Gulf of Mexico, revealed by biomarker analysis, Org. Geochem., 39, 1104-1108, 2008.
Schubotz, F., Lipp, J. S., Elvert, M., and Hinrichs, K.-U.: Stable carbon isotopic compositions of intact polar lipids reveal complex carbon flow patterns among hydrocarbon degrading microbial communities at the Chapopote asphalt volcano, Geochim. Cosmochim. Ac., 75, 4399-4415, 2011 a.

Schubotz, F., Lipp, J. S., Elvert, M., Kasten, S., Mollar, X. P., Zabel, M., Bohrmann, G., and Hinrichs, K.-U.: Petroleum degradation and associated microbial signatures at the Chapopote asphalt volcano, Southern Gulf of Mexico, Geochim. Cosmochim. Ac., 75, 4377-4398, 2011b.

Smith, A. J., Flemings, P. B., Liu, X., and Darnell, K.: The evolution of methane vents that pierce the hydrate stability zone in the world's oceans, J. Geophys. Res.-Solid Earth, 119, 6337-6356, 2014.

Suess, E., Torres, M. E., Bohrmann, G., Collier, R. W., Rickert, D., Goldfinger, C., Linke, P., Heuser, A., Sahling, H., Heeschen, K., Jung, C., Nakamura, K., Greinert, J., Pfannkuche, O., Trehu, A., Klinkhammer, G., Whiticar, M. J., Eisenhauer, A., Teichert, B., and Elvert, M.: Sea floor methane hydrates at Hydrate Ridge, Cascadia Margin, in: Natural gas hydrates: Occurrence, distribution, and detection, edited by: Paull, C., Geophysical Monograph 124, American Geophysical Union, 87-98, 2001.

Suresh, G.: Offshore oil seepage visible from space: A Synthetic Aperture Radar (SAR) based automatic detection, mapping and quantification system, Dissertation Thesis, Department of Geosciences, University of Bremen, 180 pp., 2015.

Teske, A. and Nelson, B. W.: The genera Beggiatoa and Thioploca, Prokaryotes, 6, 784-810, 2006.

Tissot, B. P. and Welte, D. H.: Petroleum formation and occurrence, Springer, Berlin, 699 pp., 1984.

Torres, M. E., Wallmann, K., Tréhu, A. M., Bohrmann, G., Borowski, W. S., and Tomaru, H.: Gas hydrate growth, methane transport, and chloride enrichment at the southern summit of Hydrate Ridge, Cascadia margin off Oregon, Earth Planet. Sci. Lett., 226, 225-241, 2004.

Treude, T., Boetius, A., Knittel, K., Wallmann, K., and Jorgensen, B. B.: Anaerobic oxidation of methane above gas hydrates at Hydrate Ridge, NE Pacific Ocean, Mar. Ecol. Prog. Ser., 264, 1-14, 2003.

Valentine, D. L., Reddy, C. M., Farwell, C., Hill, T. M., Pizarro, O., Yoerger, D. R., Camilli, R., Nelson, R. K., Peacock, E. E., Bagby, S. C., Clarke, B. A., Roman, C. N., and Soloway, M.: Asphalt volcanoes as a potential source of methane to late Pleistocene coastal waters, Nat. Geosci., 3, 345-348, 2010.

Vernon, J. W. and Slater, R. A.: Submarine tar mounds, Santa Barbara County, Calinfornia, Bull. Am. Assoc. Petrol. Geol., 47, 1624-1627, 1963.

Weiland, R. J., Adams, G. P., McDonald, R. D., Rooney, T. C., and Wills, L. M.: Geological and biological relationships in the Puma appraisal area: From salt diapirism to chemosynthetic communities, Offshore Technology Conference, Houston, Texas, USA, 5-8 May 2008, OTC-19360-PP, 2008.

Whiticar, M. J.: A geochemial perspective of natural gas and atmospheric methane, Org. Geochem., 16, 531-547, 1990.

Williams, A. K., Lawrence, G. M., and King, M.: Exploring for deepwater petroleum systems with satellite SAR (Synthetic Aperture RADAR). Fact or Fiction? Comparing results from two of today's hotspots (Congo and Santos) with two of tomorrow's (Campeche and Cariaco) (2 Poster), Adapted 
from poster presentation of the AAPG Annual Convention, Houston, 2006, available at: http://www.searchanddiscovery. com/documents/2006/06100williams/index.htm (last access: 10 March 2016), 2006.
Williamson, S. C., Zois, N., and Hewitt, A. T.: Integrated site investigation of seafloor features and associated fauna, Shenzi field, deepwater Gulf of Mexico, Offshore Technology Conference, Houston, Texas, USA, 5-8 May 2008, OTC 19356, 2008. 